\title{
Principles of antidote
} pharmacology: an update on prophylaxis, post-exposure treatment recommendations and research initiatives for biological agents

\section{Correspondence}

Dr Sharmaine Ramasamy, Defence Science \& Technology Organisation, Human Protection and Performance Division, 506 Lorimer Street, Fishermans Bend, Vic. 3207, Australia . E-mail: sharmaine.ramasamy@dsto.defence. gov.au

\section{Keywords}

biological; anthrax; botulism; cholera; encephalitis; melioidosis; plague; Q fever; ricin; smallpox

\section{Received}

22 December 2009

Revised

12 April 2010

Accepted

20 April 2010

\author{
S Ramasamy, CQ Liu, H Tran, A Gubala, P Gauci, J McAllister and T Vo \\ Defence Science \& Technology Organisation, Human Protection and Performance Division, \\ Fishermans Bend, Vic., Australia
}

The use of biological agents has generally been confined to military-led conflicts. However, there has been an increase in non-state-based terrorism, including the use of asymmetric warfare, such as biological agents in the past few decades. Thus, it is becoming increasingly important to consider strategies for preventing and preparing for attacks by insurgents, such as the development of pre- and post-exposure medical countermeasures. There are a wide range of prophylactics and treatments being investigated to combat the effects of biological agents. These include antibiotics (for both conventional and unconventional use), antibodies, anti-virals, immunomodulators, nucleic acids (analogues, antisense, ribozymes and DNAzymes), bacteriophage therapy and micro-encapsulation. While vaccines are commercially available for the prevention of anthrax, cholera, plague, $\mathrm{Q}$ fever and smallpox, there are no licensed vaccines available for use in the case of botulinum toxins, viral encephalitis, melioidosis or ricin. Antibiotics are still recommended as the mainstay treatment following exposure to anthrax, plague, $\mathrm{Q}$ fever and melioidosis. Anti-toxin therapy and anti-virals may be used in the case of botulinum toxins or smallpox respectively. However, supportive care is the only, or mainstay, post-exposure treatment for cholera, viral encephalitis and ricin - a recommendation that has not changed in decades. Indeed, with the difficulty that antibiotic resistance poses, the development and further evaluation of techniques and atypical pharmaceuticals are fundamental to the development of prophylaxis and post-exposure treatment options. The aim of this review is to present an update on prophylaxis and post-exposure treatment recommendations and research initiatives for biological agents in the open literature from 2007 to 2009.

\section{Abbreviations}

AGP, amino-alkyl glucosaminide 4-phosphate; BoNT/A-E, botulinum neurotoxins A-E; CapD, capsule depolymerase; CBR, chemical biological radiological; CDC, Centre for Disease Control (USA); CDHS, California Department of Health Services; CDV, cidofovir; ChiSys, chitosan mucoadhesive agent; CpG, unmethylated sequences of DNA; CMRI, phase I chloroform-methanol residue; ctx, cholera toxin; ctxB, subunit B of the cholera toxin; Dstl, Defence Science and Technology Laboratories (UK); DSTO, Defence Science and Technology Organisation (Australia); EEEV, Eastern equine encephalitis virus; EEV, equine encephalitis virus; EF, oedema factor; F1, fraction 1 capsular antigen; FDA, Food and Drug Administration (US); flaA-E, flagellin proteins A-E; G-CSF, granulocyte colony-stimulating factor; Had5, human adenovirus serotype 5; HC, heavy chain; HE-BAT, heptavalent botulinum antitoxin; HGS, Human Genome Sciences; IFN, interferon; INA, iodonaphthylazide; IND, investigational new drug; LC, light chain; LF, lethal factor; LT, heat-labile enterotoxin; mAbs, monoclonal antibodies; MVA, Modified vaccinia Ankara; NE, non-toxic mucosal adjuvant; ODN, oligodeoxynucleotides; PA, protective antigen; pAbs, polyclonal antibodies; PBT, pentavalent botulinum toxoid; pcDNASHc, conventional plasmid DNA vaccine; PPMO, peptide-conjugated phosphorodiamidate morpholino oligomers; pSCARSHc, plasmid DNA replicon vaccine; rhAPC, recombinant-activated protein C; rPA, recombinant protective antigen; rRV, RTA vaccine; RTA, ricin toxin A-chain; SIN, Sindbis; scFv, single-chain Fv; siRNAs, short interfering RNAs; SFV, Semliki Forest virus; TMP-SMX, trimethoprim sulphamethoxazole; USAMRIID, US Army Medical Research Institute of Infectious Diseases; VEEV, Venezuelan equine encephalitis virus; WEEV, Western equine encephalitis virus; WHO, World Health Organisation 


\section{History of biological agents}

The use of biological agents to evoke fear and cause casualties and death has a long history, dating back before the middle ages. The first known use of a biological agent was in 600 BC when Helleborus root (active ingredients: protoanemonin, steroidal saponines and bufadienolides) was used to contaminate water supplies in the siege of Kirrha (Smart, 1997). In the middle ages, the Polish used projectiles filled with saliva from rabid dogs against enemies in 1650, plague-infected cadavers were deposited in Reval, Estonia by Russians in 1710 (Smart, 1997), and in 1763 smallpox-infected blankets were distributed to Native American Indians by the British (Smart, 1997).

The deliberate use of biological agents has continued in more modern times with the use of cholera and plague by the Japanese during their invasion of China (1940-1944) (Robinson and Leitenberg, 1971), and the testing of aerial bombs and cannon shells for the dissemination of anthax spores in Scotland (1941-1942) (Robinson and Leitenberg, 1971). The assassination of Georgi Markov with ricin via a modified umbrella on 7 September 1978 (Harris and Paxman, 1982) further highlights the evolution of dissemination techniques for biological agents.

More recently, biological agents have been used outside the military sphere and in the civilian domain. The use of salmonella by the Rajneeshi sect in 1984 to influence US elections (Torok et al., 1997), the several failed attempts by Aum Shinrikyo to disseminate botulinum toxins and anthrax spores (1990-1995) (Olson, 1999) and the anthrax letters distributed in the USA shortly after the 9/11 attack on the World Trade Centre Towers in 2001 (Jernigan et al., 2002) are evidence of non-state-based groups intentionally using biological agents in terrorist activities.

\section{Change of the war environment}

The use or potential use of biological agents has generally been confined to military-led conflicts. However, the face of war has changed significantly in the past few decades. The days of conventional, military-led war-fighting with a readily-identifiable enemy are becoming less frequent.

This change in the war environment is important for governments to consider in developing strategies for preventing and preparing for attacks by insurgents. In conventional combat, operations tend to be driven by military strategy. However, in counterinsurgency, it is intelligence and information that
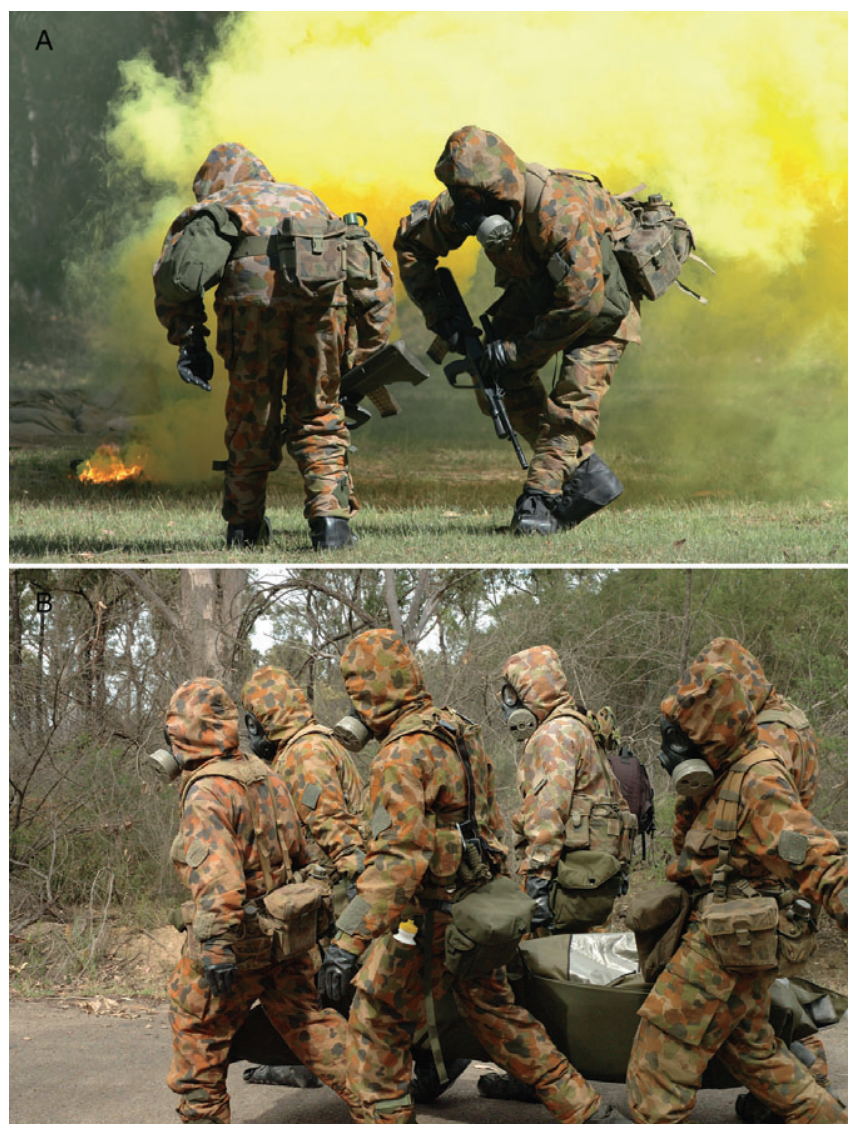

\section{Figure 1}

Soldiers (A) donning chemical and biological (CB) protective suits and $(B)$ carrying a casualty in a CB protective stretcher (photographs courtesy of the Combat Arms Training Centre).

tend to drive operations. Therefore, the best way to combat the asymmetric nature of unconventional warfare, such as biological agents, is to develop and maintain capabilities that assist with the prevention of, and response to, biological agents that may pose a threat to societal security. These areas include personal protective equipment (Figure 1), detection technology and the development of pre- and postexposure medical countermeasures.

Although the probability of an incident involving a biological agent is relatively low, the high impact risk associated with such an event necessitates that biological agents are classified as weapons of mass destruction. In contrast to conventional weapons, relatively small amounts of biological agents are capable of causing great morbidity and mortality. In addition to the burden of casualties and possible deaths on the healthcare system, an incident involving a biological agent would undoubtedly have an impact on other areas of infrastructure, including first-responder agencies, the economy, travel and tourism. Hence, one of the 
major challenges with preparing for an incident involving a biological agent is not necessarily whether to have a particular capability, but the scale to which a capability should be resourced.

\section{Current treatment of biological agents}

Given the delayed onset of common symptoms that can occur following exposure to a biological agent, healthcare professionals could play a vital role in informing first responders of a potential agent. This information is imperative in preparing a response plan (including the use of personal protective equipment), preventing further casualties and/or deaths and developing and implementing appropriate decontamination arrangements.

There are a wide range of prophylactics and treatments being developed to combat the effects of biological agents. These include antibiotics (for both conventional and unconventional use), antibodies, anti-virals, immunomodulators, nucleic acids (analogues, antisense, ribozymes and DNAzymes), bacteriophage therapy and micro-encapsulation. Interestingly, despite the numerous medical advances of the past few decades, the mainstay treatment for a number of biological agents is still basic supportive care. However, given the array of research approaches available, much research is still being undertaken to combat biological agents.

Pettineo et al. (2009) have undertaken an extensive review of current clinical therapeutic countermeasures for biological and chemical weapons; however, they did not cover the recent research advances in potential treatments. This review aims to present an update on prophylaxis and postexposure treatment recommendations and research initiatives for biological warfare or bioterror agents (anthrax, botulism, cholera, viral equine encephalitis, melioidosis, plague, $\mathrm{Q}$ fever, ricin and smallpox). It focuses on research advances and medical countermeasures of treatment of biological agents in data published from 2007 to 2009 (Table 1).

\section{Anthrax}

For a brief summary of the type, mode/mechanism of action and signs and symptoms of anthrax infection, please refer to Table 1.

\section{Current prophylaxis for anthrax}

There are two licensed anthrax vaccines available (Little, 2005; Wang and Roehrl, 2005). The US anthrax vaccine adsorbed (AVA; Emergent BioDefense Corporation; also known as BioThrax ${ }^{\oplus}$, Emer- gent Biosolutions Incorporated, Rockville, MD, USA) is extracted from a cell-free culture filtrate of an unencapsulated, toxin-producing strain of Bacillus anthracis (V770-NP1R). The UK vaccine (Health Protection Agency) is prepared from a similar strain called Sterne 34F2. Both vaccines contain the protective antigen (PA) adsorbed to aluminium hydroxide and contain small amounts of lethal factor (LF) and oedema factor (EF). The vaccines are both effective against anthrax infection when administered prophylactically, although the vaccination protocols differ (Little, 2005; Wang and Roehrl, 2005; Scorpio et al., 2006). The US vaccine is administered in a six-dose primary series at 0,2 and 4 weeks and 6,12 and 18 months with an annual booster, while the UK vaccine requires four single injections: three injections 3 weeks apart, followed by a 6 month dose, with an annual booster.

For post-exposure prophylaxis against inhalation anthrax the Centre for Disease Control and Prevention (CDC) recommends that the vaccine AVA be used at 0,2 and 4 weeks in combination with selected oral antibiotics. The combined use of AVA and antibiotics has been shown to prevent inhalation anthrax (Schneemann and Manchester, 2009) and may also shorten the required period of antibiotic therapy (Bossi et al., 2004a). However, this regime has not been approved by the United States Food and Drug Administration (FDA). Caution should be taken with children as the PA component of the vaccine may associate directly with the toxin components produced by the invading bacterium thereby potentially augmenting intoxication (Aulinger et al., 2005).

Although current human anthrax vaccines are effective against anthrax, they still suffer from batch-to-batch variation in composition, require multiple doses and yearly booster injections and have been associated with occasional adverse reactions (reactogenicity) (Pittman et al., 2001; Pittman et al., 2004). These limitations have prompted the development of novel vaccines that are less reactogenic, but equally efficacious with fewer doses. Research efforts focus on: (i) development of subunit vaccines targeting PA (and to a lesser extent $\mathrm{EF}$ and LF); (ii) evaluation of alternative vaccine delivery routes (e.g. i.m. and mucosal administration); and (iii) identification of new vaccine targets (e.g. spore and capsule antigens). Excellent reviews have been published on a number of the major achievements (Brey, 2005; Little, 2005; Wang and Roehrl, 2005; Scorpio et al., 2006).

Mucosal vaccination has proven to be a practical, non-invasive and efficacious method for the induction of both mucosal and systemic immune responses. Recently, a mucosal anthrax vaccine, 


\section{Table 1}

Summary of biological agents including type, mode/mechanism of action and signs and symptoms of infection

\begin{tabular}{|c|c|c|c|}
\hline Biological agent & $\begin{array}{l}\text { Bacteria, virus or } \\
\text { toxin? }\end{array}$ & $\begin{array}{l}\text { Mode/mechanism of } \\
\text { infection/intoxication }\end{array}$ & Signs and symptoms \\
\hline Anthrax & $\begin{array}{l}\text { Rod-shaped, } \\
\text { Gram-positive and } \\
\text { spore-forming } \\
\text { bacterium }\end{array}$ & $\begin{array}{l}\text { Bacillus anthracis forms spores under } \\
\text { specific environmental conditions. Upon } \\
\text { entering the bloodstream, spores are } \\
\text { engulfed by macrophages where they } \\
\text { germinate, multiply and eventually lead } \\
\text { to macrophage lysis (Turnbull, 2002). } \\
\text { Bacilli are released into bloodstream and } \\
\text { release a toxin comprised of three } \\
\text { polypeptides: protective antigen, } \\
\text { oedema factor and lethal factor, which } \\
\text { cause death through massive oedema } \\
\text { and organ failure (Dixon et al., 1999) }\end{array}$ & $\begin{array}{l}\text { Cutaneous: boil-like skin lesion that forms an } \\
\text { ulcer with black centre (eschar) (Figure 2); } \\
\text { Gastrointestinal: vomiting of blood, severe } \\
\text { diarrhoea, acute inflammation of intestinal } \\
\text { tract, loss of appetite; } \\
\text { Inhalational: cold or flu-like symptoms with } \\
\text { (often fatal) respiratory failure. } \\
\text { All forms lead to oedema and organ failure } \\
\text { resulting in death }\end{array}$ \\
\hline Botulism & $\begin{array}{l}\text { Neurotoxins of which } \\
\text { seven serotypes exist } \\
\text { (A, B, C, D, E, F and } \\
\text { G). } \\
\text { Clostridium botulinum, } \\
\text { Clostridium } \\
\text { argentinense, } \\
\text { Clostridium baratii and } \\
\text { Clostridium butyricum } \\
\text { are known to produce } \\
\text { botulinum neurotoxins }\end{array}$ & $\begin{array}{l}\text { Botulinum neurotoxin complex contains } \\
\text { neurotoxin and other proteins (Inoue } \\
\text { et al., 1996; Cai et al., 1999). Activation } \\
\text { occurs via a protease that forms a } \\
\text { molecule consisting of a heavy chain and } \\
\text { a light chain (LC). The LC blocks the } \\
\text { release of acetylcholine by inhibiting the } \\
\text { fusion of synaptic vesicles with the } \\
\text { plasma membrane (Singh, 2000; } \\
\text { Simpson, 2004; Montecucco and Molgo, } \\
\text { 2005; Singh, 2006) }\end{array}$ & $\begin{array}{l}\text { Food-borne: nausea, vomiting, abdominal } \\
\text { cramps, diarrhoea. } \\
\text { All forms may include: cranial nerve } \\
\text { dysfunction - blurred vision, ptosis (droopy } \\
\text { eyelids), diplopia (double-vision), photophobia } \\
\text { (sensitivity to light); bulbar nerve dysfunction } \\
\text { - dysarthia (difficulty speaking), dysphonia } \\
\text { (defective use of voice), dysphagia (difficulty } \\
\text { swallowing); descending paralysis: weakness in } \\
\text { control of muscles from head to upper and } \\
\text { lower limbs; respiratory complications due to } \\
\text { upper airway obstruction or paralysis of } \\
\text { diaphragm. Symptoms and their severity are } \\
\text { dose-dependent }\end{array}$ \\
\hline Cholera & $\begin{array}{l}\text { Toxin produced by } \\
\text { Vibrio cholerae }\end{array}$ & $\begin{array}{l}\text { The cholera toxin is an oligomeric } \\
\text { complex made up of six protein } \\
\text { subunits: a single copy of the A subunit, } \\
\text { and five copies of the B subunit (part B) } \\
\text { that are connected by a disulfide bond } \\
\text { (Zhang et al., 1995). Once part B binds } \\
\text { to surface membranes, the toxin is } \\
\text { internalized by the cell and part B is } \\
\text { released following the reduction of a } \\
\text { disulfide bridge. Part A initiates a number } \\
\text { of other internal processes that lead to } \\
\text { increased adenylate cyclase activity and } \\
\text { increased cAMP, resulting in fluid and } \\
\text { electrolyte efflux (diarrhoea) }\end{array}$ & $\begin{array}{l}\text { Abdominal pain, diarrhoea, dehydration, } \\
\text { kidney failure (in severe cases) (World Health } \\
\text { Organization, 2008) }\end{array}$ \\
\hline $\begin{array}{l}\text { Encephalitis Viruses } \\
\text { (Eastern equine } \\
\text { encephalitis (EEEV); } \\
\text { Western equine } \\
\text { encephalitis (WEEV); } \\
\text { Venezuelan equine } \\
\text { encephalitis (VEEV)) }\end{array}$ & $\begin{array}{l}\text { Alphavirus from the } \\
\text { Togaviridae family. } \\
\text { Transmitted by } \\
\text { mosquitoes (Figure 3) } \\
\text { and uses birds and } \\
\text { small mammals as } \\
\text { replicating hosts }\end{array}$ & $\begin{array}{l}\text { Single-stranded RNA arbovirus gains } \\
\text { access to spinal cord and brain cells via } \\
\text { the blood stream or nerves. Entry into } \\
\text { brain cells causes damage, ultimately } \\
\text { causing cell rupture and death. Immune } \\
\text { system response causes cerebral oedema } \\
\text { which, in conjunction with the infection } \\
\text { itself, causes symptoms of viral } \\
\text { encephalitis (Wu et al., 2007b) }\end{array}$ & $\begin{array}{l}\text { General symptoms of encephalitis may } \\
\text { include: high temperature, headache, } \\
\text { photophobia, general malaise, stiff neck and } \\
\text { back, vomiting, changes in personality, } \\
\text { confusion, amnesia, seizures, paralysis, coma. } \\
\text { EEEV: encephalitis (acute inflammation of the } \\
\text { brain) with many survivors developing } \\
\text { crippling sequelae: mental retardation, } \\
\text { convulsions and paralysis. } \\
\text { WEEV: flu-like symptoms, delirium, } \\
\text { disorientation and coma. } \\
\text { VEEV: fever, malaise, rigors, headache, myalgia }\end{array}$ \\
\hline Melioidosis & $\begin{array}{l}\text { Gram-negative } \\
\text { bacterium Burkholderia } \\
\text { pseudomallei }\end{array}$ & $\begin{array}{l}\text { Bacteria multiply within the vacuoles of } \\
\text { phagocytes following internalization and } \\
\text { subsequently induce endosome lysis and } \\
\text { cell death (Cheng et al., 2003) }\end{array}$ & $\begin{array}{l}\text { Highly variable, but may include flu-like } \\
\text { symptoms such as chills, headache and joint } \\
\text { pain. May lead to abscesses in the brain, liver } \\
\text { and spleen }\end{array}$ \\
\hline
\end{tabular}




\section{Table 1}

\begin{tabular}{|c|c|c|c|}
\hline $\begin{array}{l}\text { Biological } \\
\text { agent }\end{array}$ & $\begin{array}{l}\text { Bacteria, virus or } \\
\text { toxin? }\end{array}$ & $\begin{array}{l}\text { Mode/mechanism of } \\
\text { infection/intoxication }\end{array}$ & Signs and symptoms \\
\hline Plague & $\begin{array}{l}\text { Gram-negative } \\
\text { bacterium Yersinia } \\
\text { pestis }\end{array}$ & $\begin{array}{l}\text { Following entry to bloodstream via flea } \\
\text { bite, } Y \text {. pestis adhere to and invade } \\
\text { epithelial cells (Forman et al., 2008). Y. } \\
\text { pestis can avoid phagocytosis and } \\
\text { proliferates in lymph nodes. Bacterial } \\
\text { proteins disrupt host cell protein kinase } \\
\text { activity leading to apoptosis of } \\
\text { macrophages and invasion of the immune } \\
\text { system }\end{array}$ & $\begin{array}{l}\text { Pneumonic: severe bronchopneumonia, } \\
\text { dyspnea, cough, chest pain, haemoptysis. } \\
\text { Bubonic: prostration, severe malaise, } \\
\text { headache, vomiting, chills, cough, abdominal } \\
\text { pain, chest pain, development of buboes in } \\
\text { groin and/or lymph nodes, tachycardia, } \\
\text { hypotension, leukocytosis. } \\
\text { Septicaemic: fever, chills, nausea, vomiting, } \\
\text { diarrhoea, purpura acryl cyanosis and necrosis } \\
\text { (particularly of limbs) (Worsham et al., 2007) }\end{array}$ \\
\hline Q fever & $\begin{array}{l}\text { Gram-negative } \\
\text { bacterium Coxiella } \\
\text { burnetii }\end{array}$ & $\begin{array}{l}\text { C. burnetii is most infectious in } \\
\text { immunocompetent animals and humans. } \\
\text { The microorganism is engulfed by } \\
\text { macrophages and transported systemically, } \\
\text { causing histopathological changes in the } \\
\text { lungs, liver and spleen (Russell-Lodrigue } \\
\text { et al., 2006). After uptake by host cells, } \\
\text { proliferation within the phagolysosome } \\
\text { leads to rupture of the host cell and } \\
\text { infection of a new population of host cells } \\
\text { (Hackstadt and Williams, 1981). The } \\
\text { bacteria are able to survive inside host cells } \\
\text { via their use of a secretion system known } \\
\text { as Icm/Dot, whereby they inject effector } \\
\text { proteins called Ank proteins into the host } \\
\text { (Segal et al., 2005) }\end{array}$ & $\begin{array}{l}\text { Mild to moderate flu-like symptoms including } \\
\text { headache, fever, myalgia, arthralgia, anorexia, } \\
\text { sweats and acute weight loss. Rash may occur } \\
\text { (5-20\% of cases), as may varying degrees of } \\
\text { pneumonia (presenting with cough and } \\
\text { pleural pain) and hepatitis (Parker et al., } \\
\text { 2006). Chronic disease (9\% of cases) may } \\
\text { result in endocarditis, chronic hepatitis, } \\
\text { osteomyelitis, septic arthritis, chronic } \\
\text { interstitial lung disease or aneurysm (Parola } \\
\text { and Raoult, 2007). Factors increasing risk } \\
\text { progression from acute illness to chronic } \\
\text { disease include: heart valve defects, } \\
\text { immunosuppression due to HIV, cancer } \\
\text { therapy, transplantation or pregnancy } \\
\text { (Fenollar et al., 2001) }\end{array}$ \\
\hline Ricin & $\begin{array}{l}\text { Toxin - } 64 \text { kDa } \\
\text { globular glycoprotein } \\
\text { lectin }\end{array}$ & $\begin{array}{l}\text { Toxin consists of two chains [ricin toxin } \\
\text { A-chain (RTA) and RTB]. RTB binds to } \\
\text { galactose-containing glycoproteins on cell } \\
\text { surface and triggers endocytic uptake of } \\
\text { the toxin (Day et al., 2002). Toxin is } \\
\text { relocated to Golgi apparatus via } \\
\text { endosomal transport and the two chains } \\
\text { are separated. The RTA is moved to the } \\
\text { cytosol where it inhibits protein synthesis } \\
\text { within the cell (Audi et al., 2005) }\end{array}$ & $\begin{array}{l}\text { Gastrointestinal: nausea, abdominal pain, } \\
\text { vomiting, followed by diarrhoea, cramps, } \\
\text { dilation of pupils, fever, dehydration, anuria, } \\
\text { sore throat, headache, hypotension, } \\
\text { heartburn, internal bleeding of stomach and } \\
\text { intestines, failure of liver, spleen and kidneys, } \\
\text { leading to death within } 3 \text { days from } \\
\text { circulatory collapse (Furbee and Wermuth, } \\
\text { 1997; Reed, 1998) }\end{array}$ \\
\hline Smallpox & Variola virus & $\begin{array}{l}\text { Upon entry into host lung cells, } \\
\text { double-stranded poxviruses replicate in } \\
\text { cytoplasm of cells in lymph nodes. Virus } \\
\text { then spreads to other lymphoid tissues, } \\
\text { spleen, liver, bone marrow and lung. Virus } \\
\text { produces pro-inflammatory cytokines, } \\
\text { lymphocyte apoptosis and coagulation } \\
\text { abnormalities leading to organ dysfunction } \\
\text { and multi-system failure (Jahrling et al., } \\
\text { 2007) }\end{array}$ & $\begin{array}{l}\text { Fever, tiredness, body aches, headache, } \\
\text { backache, prostration, vomiting, } \\
\text { maculopapular rash in skin (Figure } 4 \text { ), mouth } \\
\text { and throat leading to pustular rash with } \\
\text { fluid-filled blisters and scabs. Less commonly, } \\
\text { blindness resulting from corneal ulceration } \\
\text { and scarring, and limb deformities from } \\
\text { arthritis and ostomyelitis may also occur } \\
\text { ( } 2-5 \% \text { of cases) (Behbehani, 1983) }\end{array}$ \\
\hline
\end{tabular}

based on a non-toxic mucosal adjuvant (NE) and a recombinant protective antigen (rPA), was developed (Bielinska et al., 2007). Guinea pigs immunized intra-nasally (i.n.) with the vaccine were protected from an intra-dermal (i.d.) challenge $\left(1000 \times \mathrm{LD}_{50}\right)$ of $B$. anthracis Ames spores. Another mucosal anthrax vaccine composed of rPA, MPL (a toll-like 4 receptor agonist) and ChiSys (a chitosan mucoadhesive agent) is available in the form of a dry powder (Klas et al., 2008). The vaccine protects rabbits from lethal aerosol spore challenge up to 9 weeks after a single i.n. immunization.

An anthrax vaccine based on live attenuated Salmonella vaccine strain (Ty21a) has also been 


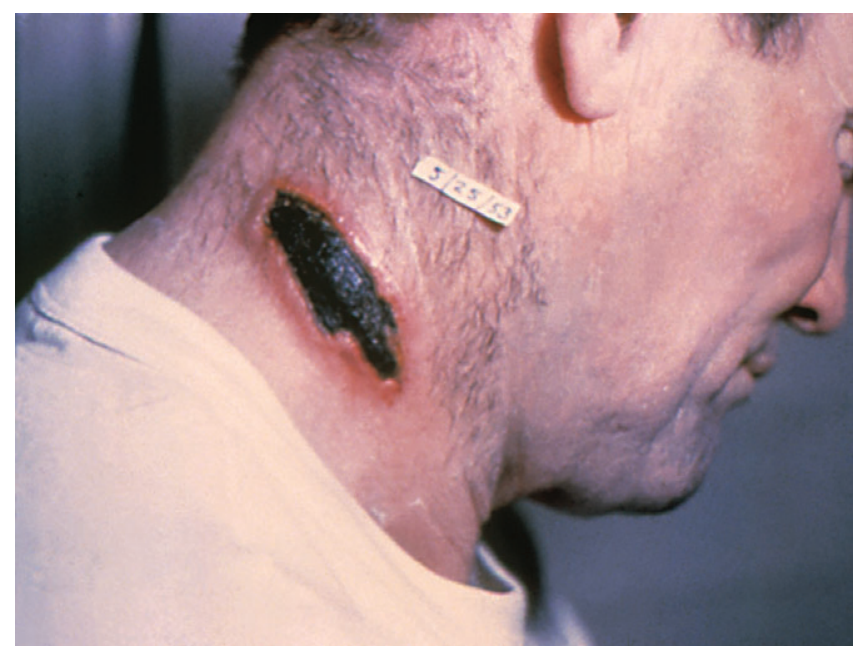

\section{Figure 2}

Cutaneous anthrax lesion on the neck (photograph courtesy of the Centre for Disease Control).

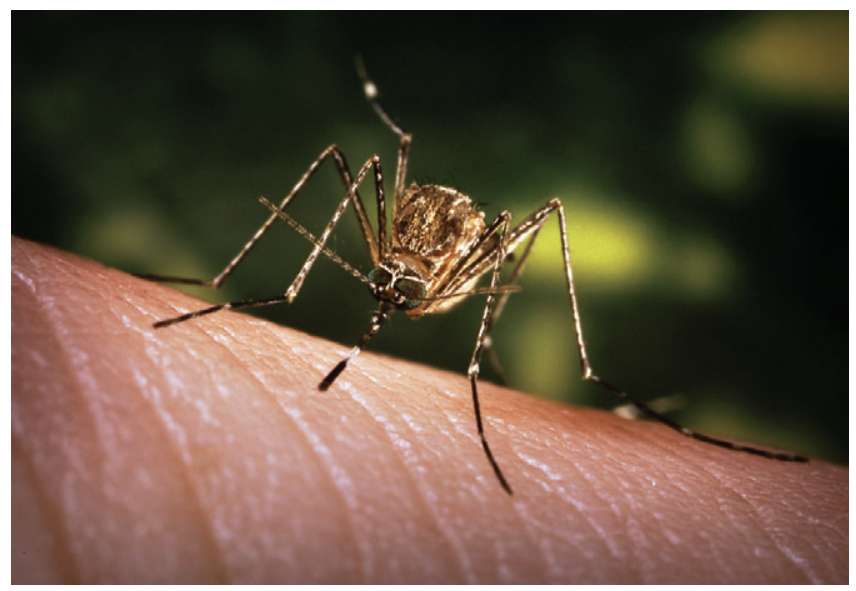

Figure 3

Anterior view of the Culex tarsalis mosquito, known to spread Western equine encephalitis, in addition to a number of other encephalitis viruses (photograph courtesy of James Gathany, Centre for Disease Control).

reported (Stokes et al., 2007). Administration of Ty21a (p.o.) expressing the full-length rPA conferred significant protection against lethal exposure to aerosolized $B$. anthracis spores in mice. Further modification of rPA by its fusion to two distinct transport proteins (HlyA and ClyA) (Baillie et al., 2008) resulted in significant PA-specific immune responses when mice were immunized with Ty21a expressing the ClyA-PA fusion protein and then boosted with either rPA or AVA. CpG (unmethylated sequences of DNA) oligodeoxynucleotides (ODN) have also been evaluated as an adjuvant for AVA (Klinman et al., 2007). Mice immunized i.p. or i.n.

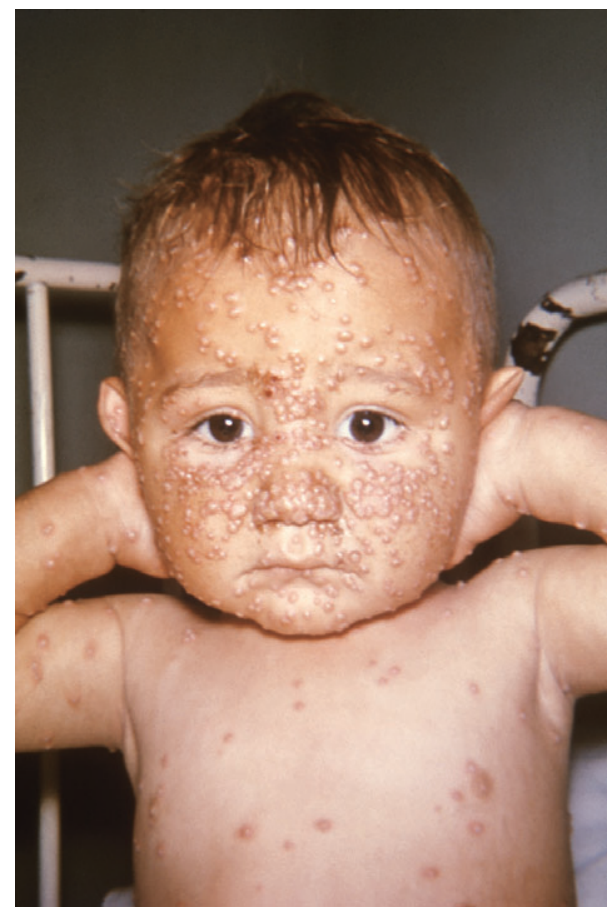

\section{Figure 4}

Characteristic maculopapular lesions of the milder form of smallpox (variola minor) on a Brazilian child (photograph courtesy of the Centre for Disease Control).

with AVA + CpG ODN showed significantly increased host immunity to infection via aerosolized anthrax spores, in contrast to animals immunized with AVA alone. Interestingly the enhanced immunity correlates with the induction of strong systemic rather than mucosal immune responses (Klinman et al., 2007).

Protection against anthrax via current anthrax vaccines is mediated largely by antibody (humoral) responses to the protective antigen (PA); however, cellular immunity has been shown to also play an important role (Glomski et al., 2007). Mice immunized with formaldehyde-inactivated spores (FIS) of a non-encapsulated $B$. anthracis strain were then challenged with an encapsulated non-toxinogenic $B$. anthracis strain. Sera, splenocytes and CD4 T lymphocytes were isolated from the FIS-induced mice and administered to naïve mice. The mice were then challenged with the encapsulated nontoxinogenic $B$. anthracis with results indicating that only interferon (IFN)- $\gamma$-producing CD4 $\mathrm{T}$ lymphocytes provide significant protection against anthrax infection. This study provides the first evidence of protective cellular immunity against encapsulated B. anthracis.

A plasmid DNA-based approach has been applied successfully to anthrax vaccine development to boost cellular immunity (Zhang et al., 2008). Vacci- 
nation of mice with plasmid constructs expressing either PA or EA1 (an S-layer antigen) produced both Th1 and Th2 cellular responses demonstrating that this approach may be used to generate durable immune responses against anthrax. This method has also been used in conjunction with a replication-defective adenovirus vector in a primeboost vaccination strategy (McConnell et al., 2007). Mice primed and boosted with plasmid DNA and adenovirus DNA, respectively, were fully protected from anthrax spore challenge. Interestingly the adenovirus-based prime-boost immunization produced 10-fold the anti-PA antibodies than AVA after a single injection.

The toxin components PA and LF are composed of four domains, of which the PA domain 4 interacts with the host cell receptor, while the LF domain 1 binds to PA63 (the active form of PA). Antibodies raised against the PA domain 4 were protective against anthrax infection when tested in mice (Flick-Smith et al., 2002). The PA domain 4 and the LF domain 1 were fused to a thermostable lichenase from the bacterium Clostridium thermocellum and then expressed in the plant Nicotiana benthamiana (Chichester et al., 2007). Immunization of mice with the fusion protein resulted in high titres of antibodies capable of neutralizing the lethal toxin in vitro.

A novel vaccine with the combined function of vaccine and antitoxin has been reported (Manayani et al., 2007). In this vaccine multiple copies of the PA-binding domain VWA of the anthrax toxin receptor ANTXR2 were expressed and displayed on the surface of an insect virus. The resultant chimeric virus particles protected rats from anthrax intoxication, and when loaded with PA, induced a potent immune response against lethal toxin challenge in a single dose without adjuvant.

Previous studies have shown that whole sporebased vaccines are more effective against virulent strains of $B$. anthracis than the current PA-based vaccines (Little and Knudson, 1986; Welkos and Friedlander, 1988; Brossier et al., 2002). However, these vaccines are unlikely to be used in humans because of safety concerns. Mice primed with suboptimal amounts of PA followed by the spore surface antigen BclA were protected from lethal anthrax spore challenge (Brahmbhatt et al., 2007). BclA promotes opsonophagocytosis of spores by macrophages thereby inhibiting intra-macrophage spore germination. More recently, spore surface antigens p5307 and ВхрB were identified (Cybulski et al., 2008). Mice immunized with suboptimal amounts of anthrax PA followed by p5307 and BxpB had enhanced protection against lethal anthrax spore challenge compared with animals immunized with
PA alone. Although antibodies raised against either antigen reduced the rate of spore germination in vitro, both produced enhanced phagocytic uptake and phagocyte-mediated spore destruction in the mice. Holistically, these results demonstrate that spore surface antigens are potential immunoenhancers to PA-based vaccines.

Catalytic mutants of $\mathrm{LF}\left(\mathrm{LF}_{\mathrm{E} 687 \mathrm{~A}}\right)$ and $\mathrm{EF}\left(\mathrm{EF}_{\mathrm{H} 351 \mathrm{~A}}\right)$ have been evaluated in combination with PA for prophylactic use. Studies in mice demonstrated the ability of $\mathrm{LF}_{\mathrm{E} 687 \mathrm{~A}}$ and $\mathrm{EF}_{\mathrm{H} 351 \mathrm{~A}}$, co-administered with $\mathrm{PA}$, to reduce lethality following lethal anthrax spore challenge (Gupta et al., 2007).

The advances in vaccine development for anthrax over the last 2 years, as outlined above, have been undertaken in preclinical animal studies and more definitive outcomes in human clinical trials are required.

\section{Current treatment for anthrax}

The FDA recommends that ciprofloxacin, doxycycline or amoxicillin be used for a period of 60 days post exposure to B. anthracis (http://www.fda.gov/). Following the bioterrorism attack of 2001, more detailed guidelines have been produced by the CDC (http://www.cdc.gov/).

The need for novel strategies to treat anthrax infection has been highlighted given that prolonged antibiotic treatment is not suitable for pregnant women and children (Schneemann and Manchester, 2009). Furthermore, antibiotics do not inhibit anthrax intoxication once critical levels of toxin are in the bloodstream. There is also the concern that antibiotic therapy will not be effective against future strains of antibiotic resistant B. anthracis (Stepanov et al., 1996; Brook et al., 2001; Schneemann and Manchester, 2009).

The most significant novel therapy has been the development of antibody-based passive immunotherapy against anthrax toxin components, primarily PA and to a lesser extent LF (Bouzianas, 2007). This has been made possible through significant funding from the US government to support the development and commercialization of antibodybased therapy. For example, Human Genome Sciences (HGS) was awarded $\$ 165 \mathrm{M}$ in June 2006 to develop and deliver 20000 doses of human monoclonal antibody (mAb) ABthrax, which targets PA, and Elusys Therapeutics Inc. was awarded $\$ 12 \mathrm{M}$ in September 2007 to produce a high-affinity humanized $\mathrm{mAb}$ to PA. Both therapeutics have completed phase I clinical trials.

In addition to the toxin components, the anthrax capsule is also critical for inducing passive immunotherapy because of its role in the early stages of infection. Recently, six mAbs specific to the 
capsule have been produced and evaluated for their ability to protect mice against inhalational anthrax (Kozel et al., 2007). Most of the antibodies conferred varying degrees of protection to inhalational anthrax in mice, most likely due to how they interact with the capsule. The most protective antibodies (F26F2 and F26G3) were identified as potential candidates for further development.

A recombinant enzyme called capsule depolymerase (CapD) has been explored as an alternative to antibody-based therapy (Scorpio et al., 2007; Scorpio et al., 2008). CapD functions to degrade the capsule and remove it from the surface of $B$. anthracis cells. Pretreatment of mice with CapD significantly enhances macrophage phagocytosis and neutrophil killing of encapsulated $B$. anthracis cells (Scorpio et al., 2007). CapD confers significant protection against anthrax by promoting in vivo phagocytic killing of encapsulated $B$. anthracis cells in mice (Scorpio et al., 2008).

\section{Botulism}

For a brief summary of the type, mode/mechanism of action and signs and symptoms of botulism, please refer to Table 1.

\section{Current prophylaxis for botulism}

There are no licensed vaccines against botulism currently available to the public. However, the $\mathrm{CDC}$ are investigating a pentavalent botulinum toxoid (PBT) vaccine. PBT is derived from formalin-inactivated, partially purified botulinum neurotoxins A-E (BoNT/A-E) (Dembek et al., 2007). The PBT dosing schedule includes a primary series of four injections ( $0.5 \mathrm{~mL}$ at $0,2,12$ and 24 weeks) followed by annual boosters (Smith and Rusnak, 2007). To date, PBT has been administered to 20000 at-risk laboratory personnel and 8000 military personnel (Bossi et al., 2004b; Dembek et al., 2007). Studies have indicated PBT to be safe with mild and self-limiting local reactions (Dembek et al., 2007).

The existing PBT (formalin-inactivated toxoid) has several drawbacks that prevent its use in mass vaccination. It is expensive as it requires cultivation of live Clostridium botulinum bacteria and there are technical difficulties as formalin inactivation tends to induce structural changes in the toxin itself, thereby implying that immunization may result in low levels of neutralizing antibodies. Jones et al. (2008) described for the first time a simple, less-time consuming and novel method for producing an inactivated toxoid that is structurally and antigenically similar to the native toxin. The resulting toxoid exhibits reduced neurotoxic activity by at least seven orders of magnitude, and is capable of raising in vivo antibody levels to 600 times those produced by formalin-inactivated toxoids (Jones et al., 2008).

Recombinant protein techniques may be utilized to develop more cost-effective vaccines. Recombinant botulinum neurotoxin heavy chain (HC) has been expressed in Escherichia coli and Pichia pastoris and assessed for protection against BoNT-induced death. Both studies showed that mice immunized with recombinant $\mathrm{HC}$ are protected against challenge with active BoNT. Sera from vaccinated mice also contained high titres of neutralizing antibodies (Webb et al., 2007; Yu et al., 2007a; Yu et al., 2009). Recombinant HC was highly immunogenic and produced high levels of antitoxin antibodies that were effective and may be used as co-treatment for botulism.

The development of a non-catalytic recombinant form of botulinum toxin has also been investigated as a vaccine candidate (Willis et al., 2008). As an example, BoNT/ $\mathrm{A}^{\mathrm{RYM}}$, a recombinant BoNT/A with two single-point mutations (R365A and Y365F) on the light chain domain renders toxins inactive by cleaving off SNAP-25. BoNT/A ${ }^{\text {RYM }}$ has been shown to be highly immunogenic as a vaccine (Pier et al., 2008). Animal studies on mice have shown that when immunized with BoNT/A ${ }^{\mathrm{RYM}}(1.0 \mu \mathrm{g})$, mice survived subsequent challenges of 10000 times that of the BoNT/A LD 50 (Pier et al., 2008).

DNA-based vaccines have also been studied as, in contrast to recombinant HC subunit vaccines, they are simple to produce and purify and are easy to store. Plasmid DNA replicon vectors derived from alphaviruses such as Sindbis (SIN) virus and Semliki Forest virus (SFV) are used to boost immune responses (Yu et al., 2007b). The immunogenicity of a plasmid DNA replicon vaccine (pSCARSHc) encoding the HC domain of BoNT/A was compared with a conventional plasmid DNA vaccine (pcDNASHc) encoding the same antigen. pSCARSHc showed greater induction of BoNT/A HC-specific antibodies in mice, resulting in greater protection against BoNT/A than pcDNASHc. The potential use of an adenovirus-vectored recombinant vaccine based on the BoNT/C HC has also been investigated (Zeng et al., 2007). The vaccine elicited a robust immune response against BoNT/C over a prolonged period. This indicated that both types of vaccines can provide protection against BoNTs in mice to varying degrees, and therefore are promising vaccine candidates for botulism.

\section{Current treatment for botulism}

Treatment for botulism includes antitoxin therapy and supportive care. Supportive care often includes 
mechanical ventilation and feeding by enteral tube. The duration of care varies from a few days to 2-6 weeks (or longer) in severe cases (Dembek et al., 2007). Effective antitoxin therapy can be achieved when it is administered to patients within $24 \mathrm{~h}$ of patients exhibiting neurologic signs of botulism (Dembek et al., 2007). The neutralizing antibodies prevent further progression of paralysis by binding to the toxin itself, thereby preventing it from binding to presynaptic membrane receptors. This timely administration of antitoxin therefore minimizes the severity of the disease.

Currently, there are two FDA-approved antitoxin products available: (i) the bivalent botulinum equine antitoxin (BoNT/A and BoNT/B; CDC); and (ii) the human botulism immune globulin [BabyBIG; California Department of Health Services (CDHS)], for adults and infants, respectively (Dembek et al., 2007). Baby-BIG is the product of pooled plasma from adults immunized with PBT followed by subsequent development for high titres of neutralizing antibodies against BoNT/A and BoNT/B. Therefore, in contrast to adult antitoxin product, Baby-BIG does not pose a risk to anaphylaxis or life long hypersensitivity to equine antigens (Dembek et al., 2007). An investigational human botulinum immune globulin against toxin serotype $\mathrm{E}$ is also currently available from CDHS, while CDC has an investigational equine antitoxin product for BoNT/E. With declining titres for BoNT/E, CDC no longer provides the previously available trivalent equine botulinum antitoxin (for BoNT/A, BoNT/B and BoNT/E) (Dembek et al., 2007).

The US Army Medical Research Institute of Infectious Diseases (USAMRIID) currently has two investigational equine antitoxin preparations that target all seven toxin serotypes that produce botulism: (i) equine heptavalent botulinum antitoxin (known as HE-BAT); and (ii) equine heptavalent botulinum antitoxin $\mathrm{F}\left(\mathrm{ab}^{\prime}\right)_{2}$. To reduce hypersensitivity reactions, the constant domains (Fc fragment) of the equine immunoglobulin molecule are cleaved off. Studies show both heptavalent antitoxin products to be protective in vivo (in mice and non-human primates) and in vitro with products able to neutralize all seven serotypes (Dembek et al., 2007). Both products would be considered for the treatment of botulism in the case of accidental or intentional incidents.

Side effects of equine antitoxin polyclonal antibodies (pAbs) include serum sickness and hypersensitivity reactions. Other challenges associated with these drugs include limited supply, batch-to-batch variation and importantly, the potential risk of infectious disease transmission, making antitoxins less effective as a prophylaxis treatment for post- exposure populations. Neutralizing monoclonal antibodies (mAbs) have proven to be valuable therapeutic agents when compared with pAbs. mAbs can be produced in unlimited supply, do not require a source of immune donors, are consistent from batch to batch and have no infectious risk.

\section{Cholera}

For a brief summary of the type, mode/mechanism of action and signs and symptoms of cholera, please refer to Table 1 .

\section{Current prophylaxis for cholera}

Prophylactic treatments for cholera have not changed significantly in recent decades. The provision of clean water and proper sanitation are still regarded as the most appropriate measures for cholera control.

There are currently three oral vaccines available for cholera, namely:

1 The WC/rBS vaccine (also known as Dukoral) that is the only internationally available vaccine (licensed in approximately 20 countries) and consists of killed whole-cell Vibrio cholerae $\mathrm{O} 1$ with purified recombinant $\mathrm{B}$ subunit of the cholera toxin (ctx). This vaccine is most commonly administered to travellers; however, not all countries advocate this practice, including the USA. It is administered as two doses given 1-6 weeks apart and provides $\sim 85 \%$ efficacy 6 months after immunization. Efficacy and duration of immunity can vary considerably between individuals as it has been known to last up to 3 years in some individuals (World Health Organization, 2008).

2 A variant of the $\mathrm{WC} / \mathrm{rBS}$ vaccine containing no recombinant $\mathrm{B}$ subunit has been licensed in Vietnam and provides similar protection $(66 \%, 10$ months). This vaccine is cheaper to produce due to the absence of the recombinant $\mathrm{B}$ subunit and an improved formulation is currently undergoing phase III clinical trials in India (Anh et al., 2007).

3 The CVD 103-HgR vaccine (previously and currently known as Orochol and Mutacol, respectively) is a live, attenuated, single-dose vaccine with a protection rate of $95 \%$ to $V$. cholerae Classical and $65 \%$ to $V$. cholerae El Tor, 3 months after vaccination. Although this vaccine is licensed in some countries, its long-term efficacy remains uncertain (World Health Organization, 2008).

Development of vaccines for cholera is challenging as there are no other animal species who are natural hosts for cholera, nor do they show 
significant disease symptoms. Infant mice are susceptible to infection and are used as models for evaluation of potential vaccines, but this only allows for the study of short-term, passive immunity (Nygren et al., 2008). Consequently, vaccine development for cholera has been slow, despite intensive research efforts.

Peru-15, a live, single-dose vaccine manufactured as CholeraGarde by Celldex Therapeutics (previously AVANT Immunotherapeutics), is currently being evaluated in phase II clinical trials (Qadri et al., 2007; Sharma et al., 2008a; http://clinicaltrials.gov/show/NCT00741637). This vaccine is active against the prevalent pandemic strain (biotype El Tor), and studies to date have found it to be safe, immunogenic and protective. The major advantage of Peru-15 is its administration as a single dose, which makes it easier for mass administration.

Intra-nasal administration has been demonstrated to be an effective route of administration for vaccines. Vaccination (i.n.) using live and killed $V$. cholerae without adjuvants has been shown to elicit strong serum and intestinal immune responses in mice (Nygren et al., 2008). Similarly, a single dose (i.n.) of the variant of $V$. cholerae strain, IEM108 (IEM109), confers full protection in rabbits (Yan et al., 2007).

Several $V$. cholerae proteins have immunogenic effects in animals. Mice immunized (i.n., i.g. and i.p.) with the outer membrane vesicles of $V$. cholerae were found to have long-term immunity that was also passed on to offspring (Schild et al., 2008). Hence, these proteins could be potential vaccine candidates for $V$. cholerae and for other bacteria that produce similar proteins. In addition, cellular immune responses elicited by $V$. cholerae flagellin proteins (flaA-flaE) highlight the importance of these proteins in inducing inflammatory responses, thereby informing approaches for the development of future vaccines (Harrison et al., 2008).

The ctx is the main cause of severe disease symptoms and is therefore the target of neutralizing antibodies in immune hosts. Typically, subunit B of this toxin (ctxB) is a useful antigen in vaccines, but it is required in large quantities to elicit a sufficient immune response. The recombinant production of this toxin may be used in vaccines; however, technical difficulties and cost make implementation of the $\mathrm{WC} / \mathrm{rBS}$ vaccine in poor countries a challenge. Consequently, two genetically engineered strains of $V$. cholerae expressing increased amounts of the ctx were developed (Rhie et al., 2008a,b). A recombinant strain, O395-N1-E1, was found to induce neutralizing antibodies in vaccinated mice and may be an alternate strain for the development of a whole-cell killed vaccine (Rhie et al., 2008a). The protection afforded by these strains is yet to be determined.

Subunit B of the cholera toxin expressed in transgenic rice plants has been shown to be cheap to produce and highly stable at room temperature and is therefore being considered as a potential 'edible vaccine' (Oszvald et al., 2008; Yuki and Kiyono, 2008). MucoRice, the Japanese vaccine candidate, induced systemic and mucosal immunity, remained stable at room temperature for up to 1.5 years and was protected from pepsin digestion in vitro (Yuki and Kiyono, 2008). Similarly, transgenic tomatoes expressing the ctx, or a combination of the ctx and the accessory colonization factor subunit A (acfA) or the toxin co-regulated pilus subunit A (tcpA), were produced (Jiang et al., 2007; Sharma et al., 2008a,b). Mice fed transgenic tomatoes expressing the ctx displayed serum and mucosal immunity (Jiang et al., 2007). The protective immunity of these candidates is yet to be determined.

Previous studies have observed a notable level of cross-protective immunity generated by the $E$. coli heat-labile toxin and the ctx. This is due to the homology ( $80 \%)$ that these proteins share. Transgenic carrots expressing the $E$. coli heat-labile toxin were fed to mice and resulted in systemic and intestinal immunity to the ctx (Rosales-Mendoza et al., 2008). 'Edible vaccines' are still at the infantile stage of development, but demonstrate the potential value of transgenic foods in vaccine development.

\section{Current treatment for cholera}

The mainstay treatment of cholera is rehydration therapy (p.o. or i.v.), which often results in full recovery without the need for further treatment. Antibiotics will assist in reducing the duration and severity of illness, but this regime is not implemented in large outbreak scenarios due to cost and the development of antimicrobial resistance. Tetracycline has been the traditional antibiotic of choice for the treatment of cholera; however, widespread resistance has led to more prevalent use of doxycycline, ciprofloxacin, erythromycin, chloramphenicol and azithromycin. Consequently, resistant strains to these antibiotics have also emerged and epidemiological surveillance of circulating strains is of utmost importance in the selection of appropriate antibiotic treatments.

Research on alternative compounds that have antimicrobial activity have been undertaken to combat antibiotic resistance. Peptides derived from granulysin (a protein naturally activated in human killer cells and $\mathrm{T}$ lymphocytes in response to infection) have demonstrated anti- $V$. cholerae properties in vitro and in suckling mice (da Silva et al., 2008). 
Toxicity studies on human peripheral blood mononuclear cells show these peptides to have low in vitro toxicity while sialyloligosaccharides, which mimic the cell receptor to which ctx binds, efficiently inhibit ctx (Sinclair etal., 2008). These nondigestible compounds may be useful for cholera management as prophylaxis administered in food and drink. Europium III chloride, a molecule that has low oral toxicity, inhibits the binding of the ctx to receptors (Williams and Jenkins, 2008) while efflux pump inhibitors have been shown to effectively increase $V$. cholerae susceptibility to antibiotics and decrease production of virulence factors (Bina et al., 2009). Thus, these compounds may have future pharmaceutical applications in the treatment of cholera without the use of antibiotics.

Although the benefits of zinc supplementation in patients with acute or persistent diarrhoea have been known since the 1970s, the impact of zinc supplementation on severe diarrhoea, such as that caused by $V$. cholerae had not previously been studied. Trials on zinc supplementation in children with cholera demonstrate that zinc supplementation can significantly reduce the duration of diarrhoea and stool output during cholera (Roy et al., 2008). This suggests that zinc may be administered as a cheap and effective therapeutic for the treatment of cholera and may be particularly useful in situations where rehydration therapy or antibiotics are not immediately available.

The beneficial effect of leaves from the neem plant (Azadirachta indica) on gastrointestinal disorders, such as infection with $V$. cholerae, is widely known in indigenous Indian populations. Neem leaf extract was shown to have significant antibacterial, antisecretory and antihaemorrhagic properties in mice infected with $V$. cholerae (Thakurta et al., 2007).

\section{Equine encephalitis viruses}

For a brief summary of the type, mode/mechanism of action and signs and symptoms of viral encephalitis infections, please refer to Table 1.

\section{Current prophylaxis for equine encephalitis viruses}

There are currently no licensed vaccines available for any of the equine encephalitis viruses (EEV). Vaccines with investigational new drug (IND) status are available for laboratory personnel at risk. They include a live attenuated vaccine for Venezuelan EEV (VEEV) and inactivated vaccines for Eastern EEV (EEEV) and Western EEV (WEEV). However, immunogenicity with these vaccines is often poor and immunity is short-lived.
The role and function of viral structural proteins, particularly the capsid protein, are important in the development of attenuated vaccines. The capsid proteins of EEEV, VEEV and presumably, WEEV, play a part in the inhibition of cellular transcription and the evasion of the host IFN response (Aguilar et al., 2007; 2008b; Garmashova et al., 2007). Attenuation of the TC-83 VEEV vaccine was achieved by replacing the N-terminus of the capsid protein with the SIN virus counterpart (Garmashova et al., 2007). In addition, further elucidation of the complex role that structural and non-structural protein (NSP) genome regions of EEEV play in neurovirulence has provided insight into the future development of live attenuated vaccines and anti-virals (Aguilar et al., 2008a).

Chimeric vaccines utilize a SIN virus backbone expressing either EEEV or VEEV structural proteins. Mice vaccinated with a SIN/EEEV vaccine were protected against live virus challenge and developed high titres of neutralizing antibodies (Wang et al., 2007a). This vaccine has also been shown to have reduced infectivity in mosquitoes, with the impact on dissemination and potential transmission being mosquito species-specific (Arrigo et al., 2008). A SIN/ VEEV vaccine has been further evaluated in immunodeficient mice and shown to be highly effective (Paessler et al., 2007). A chimeric VEEV vaccine based on an equine herpesvirus type 1 has been shown to be genetically stable and conferred full protection to mice from lethal challenge with VEEV (Rosas et al., 2008). Further evaluation of the chimeric vaccines in mice may provide the opportunity to identify prognostic markers that correlate with protection against encephalitis.

Adenovirus-based vaccines, such as the human adenovirus serotype 5 (Had5)-vectored WEEV vaccine (Wu et al., 2007a), have been shown to elicit a rapid, long-lasting and robust immune response in mice (Barabe et al., 2007). Mice were protected from challenge with both homologous and heterologous strains of WEEV, including the highly virulent Fleming strain. One of the concerns with adenovirus-vectored vaccines is that existing immunity to the vector can be detrimental for homologous boosting. Therefore, it should be noted that co-administration of adenovirus-vectored VEEV vaccine and $\mathrm{CpG}$ can augment antibody responses; however, this is not the case for the transgene product (Perkins et al., 2008).

The development of attenuated VEEV vaccines by mutating the promoter elements in the VEEV genome, without affecting the amino acid sequence of the NSP, has been demonstrated (Michel et al., 2007). V3526 is a live attenuated VEEV vaccine derived by site-directed mutagenesis from a full- 
length infectious VEEV isolate. It has been shown to be safe and efficacious in horses (Fine et al., 2007), is not significantly more neurovirulent than TC-83 when tested in non-human primates (Fine et al., 2008) and is able to protect mice from infection of VEEV via mosquito bite as well as i.p. challenge (Charles et al., 1997; Rao et al., 2006). This approach to vaccine development should be conducted with caution as it can produce rapid adoption of mutations in the NSP. Some of the adaptations were observed after only a few rounds of infection, highlighting the plasticity of these viruses and their evolutionary potential. Indeed, this may limit their potential as vaccine candidates against EEV.

A vaccine candidate developed by irradiating 1,5iodonaphthylazide (INA)-treated VEEV, has been shown to protect mice from lethal challenge. This process inactivates the virus completely and causes the INA to selectively bind to transmembrane proteins in the viral envelope (Sharma et al., 2007). This research may be useful in developing a vaccine that is immunogenic and free from residual virulence.

Interferon is a cytokine involved in the host defence mechanism against viral infection. Strategies to boost the levels of IFN in the host have been investigated to determine if increased IFN levels can be protective against challenge. A hamster model for WEEV infection has been developed to study the effects of exogenous IFN (alfacon-1) and an IFN inducer $\left(\right.$ Ampligen ${ }^{\circledR}$ ) on WEEV disease. The survival rate was $100 \%$ when both were administered prophylactically $4 \mathrm{~h}$ before viral challenge. Alfacon-1treated animals had a significantly reduced brain viral titre, with virus loads below the limits of detection. Ampligen ${ }^{\circledast}$ also produced a significant reduction in brain viral titre, despite virus being detected in $60 \%$ of animals. In addition, a HAd5 vector expressing murine IFN administered $24 \mathrm{~h}-1$ week prior to WEEV challenge protected mice (Wu et al., $2007 \mathrm{~b}$ ). This vaccine also delayed the progression of WEEV infection and partially protected mice when administered $64 \mathrm{~h}$ post lethal challenge.

Despite affording only partial protection to mice administered a lethal challenge of WEEV, a recombinant E2 protein of WEEV has elicited strong humoral and cell-mediated responses when used to immunize mice (Das et al., 2007). Thus, recombinant techniques may also be useful in the development of EEV vaccines.

\section{Current treatment for equine encephalitis viruses}

There are no antiviral therapeutics available for the viral encephalitis. Supportive care via i.v. fluids, a respirator, sedatives, analgesics, corticosteroids to reduce brain swelling and anticonvulsants to treat seizures are recommended.

Most antiviral therapy focuses on the inhibition of viral replication, such as RNA interference. This cellular process involves short interfering RNAs (siRNAs) and small double-stranded RNA molecules directing the degradation of complementary messenger RNAs. A combination of four siRNAs targeting conserved sequences of divergent VEEV strains has been demonstrated to inhibit replication of six strains of VEEV in vitro (O'Brien, 2007). Interestingly, this work raises the issue of the development of resistance to siRNA as one strain was able to confer resistance to siRNAs.

Peptide-conjugated phosphorodiamidate morpholino oligomers (PPMO) inhibit viral replication through sequence-specific steric blockade of viral RNA. Mice receiving PPMO before and after challenge with VEEV all survived and did not have any detectable virus 2-4 days post challenge. In contrast, mice receiving PPMO only post challenge had partial protection and viral titres in tissue samples were reduced (Paessler et al., 2008).

Antiviral agents that inhibit viral replication were evaluated as treatments for VEEV infection using a lethal mouse model (Julander et al., 2008b). (-)Carbodine was shown to be effective in improving disease parameters even when administered up to 4 days post infection (Julander et al., 2008a). Further, a novel 3-sulphonamido-quinazolin-4(3H)-one derivative, given at a dose below the cytotoxic concentration, was moderately active in inhibiting the replication of VEEV in vitro (Selvam et al., 2007).

Identifying agents that interfere with viral assembly is an approach that may provide a new source of antiviral agents. RNA thioaptamers are small RNA sequences that bind to proteins. Several thioaptamers were isolated by in vitro combinatorial selection and assessed for their binding affinity to the capsid protein of VEEV. One thioaptamer was shown to have a high binding affinity and specificity for the capsid protein (Kang et al., 2007).

Melatonin has been shown to be effective in treating VEEV infection by decreasing nitrite and lipid peroxidation generated by VEEV infection and increasing IL-1 $\beta$ (a cytokine capable of increasing inducible nitric oxide synthase production) in the brain (Valero et al., 2007). However, the inhibitory effect (if any) of melatonin on VEEV replication is yet to be determined.

A mouse anti-VEEV antibody has been humanized to combat the problem of a human anti-mouse antibody response. The humanized antibody binds to VEEV E2 protein in a dose-dependant manner, and demonstrated strong neutralizing capacity in a standard plaque reduction assay (Hu et al., 2007). 
This antibody is likely to be further evaluated as an immunotherapeutic agent against VEEV.

\section{Melioidosis}

For a brief summary of the type, mode/mechanism of action and signs and symptoms of melioidosis, please refer to Table 1.

\section{Current prophylaxis for melioidosis}

Currently there is no licensed vaccine available for melioidosis. Trimethoprim sulphamethoxazole (TMP-SMX; p.o.) is recommended for post-exposure prophylaxis in the case of a biological attack (Bossi et al., 2004c), and for immunosuppressed patients, as melioidosis is more common and more severe in these individuals (Davis et al., 2003).

Melioidosis prophylaxis focuses on improving our knowledge of the natural history of infection of Burkholderia pseudomallei in both animal models and the human host. This includes identification of potential virulence factors using bioinformatics (Haraga et al., 2008) and signature-tagged mutagenesis (Cuccui et al., 2007). It also involves further characterization of protective immune responses, including induction of cell-mediated immunity (Barnes and Ketheesan, 2007), the bactericidal function of macrophages (Barnes et al., 2008), the role of neutrophils in infection (Easton et al., 2007) and the relationship between route of immunization and protective Th1 inflammatory responses (Tan et al., 2008).

A number of antigens have been identified and assessed as potential vaccine candidates. Defence Science and Technology Laboratories (Dstl, UK) have identified $35 \mathrm{~B}$. pseudomallei surface proteins using a biotinylation approach and have screened them for immunogenicity using sera from convalescent melioidosis patients (Harding et al., 2007). Nine of these proteins were considered immunoreactive and will be further evaluated as vaccine candidates (Harding et al., 2007). In addition, several proteins of the ATP-binding cassette system of $B$. pseudomallei have been used to immunize Balb/c mice, with significant protection from challenge seen with two of these proteins, LolC and PotF (Harland et al., 2007). LolC also demonstrated enhanced protection when complexed with $\mathrm{CpG}$ in adjuvant ISCOM (Harland et al., 2007).

Other vaccine strategies include immunization with attenuated live mutants and low-dose, live immunization. Although immunization with attenuated mutants provided some protection from acute i.p. and i.n. challenge, it did not improve survival against chronic melioidosis nor i.v. infec- tion (Breitbach et al., 2008). Immunization of mice with low concentrations of live B. pseudomallei demonstrated enhanced delayed-type hypersensitivity responses when compared with immunization using heat-killed B. pseudomallei in complete Freud's adjuvant (Barnes and Ketheesan, 2007).

Murine mAbs specific to $B$. pseudomallei have been used to generate peptide mimotopes. These peptides, conjugated with thyroglobulin and used to immunize Balb/c mice, were shown to delay the time to death in these animals following challenge with live B. pseudomallei (Legutki et al., 2007).

Evaluation of amoxicillin/clavulanic acid, doxycycline and co-trimoxazole (p.o.) as both pre- and post-exposure prophylaxis has been performed in Balb/c mice $48 \mathrm{~h}$ prior to aerosol challenge, and at 0 , $10,24,48 \mathrm{~h}$ and up to 10 days post challenge (Sivalingam et al., 2008). All animals succumbed to infection if the antimicrobial was administered $48 \mathrm{~h}$ or later following exposure. However, when co-trimoxazole was administered within $24 \mathrm{~h}$ post infection, all mice survived. As pre-exposure prophylaxis, doxycycline and co-trimoxazole had survival rates of $80 \%$ and $100 \%$ respectively. All animals receiving amoxicillin/clavulanic acid succumbed to challenge, suggesting this drug is not suitable as a prophylactic against melioidosis (Sivalingam et al., 2008).

\section{Current treatment for melioidosis}

The current recommended treatment for severe melioidosis is i.v. administration of ceftazidime or a carbapenem, with or without TMP-SMX, for 10-14 days or longer as clinically indicated (Cheng and Currie, 2005). Meropenem, imipenem and cefoperazone-sulbactuam are also active against $B$. pseudomallei (Simpson et al., 1999; Chetchotisakd et al., 2001; Cheng et al., 2004). TMP-SMX (p.o.) for 12-20 weeks, with or without doxycycline is recommended (Cheng and Currie, 2005). Amoxicillinclavulanate is an alternative for pregnant women, children and patients with intolerance to the first line therapy but is much less effective (Suputtamongkol et al., 1994). At the Royal Darwin Hospital, the initial phase of treatment for patients with melioidosis-induced septic shock is meropenem plus granulocyte colony-stimulating factor (G-CSF) (Cheng and Currie, 2005).

In vitro antimicrobial susceptibility testing was performed on $B$. pseudomallei isolates collected in Malaysia between 1978 and 2003. The organisms were assessed for susceptibility to imipenem, meropenem, ertapenem, moxifloxacin and azithromycin using the $E$-test minimum inhibitory concentration method. All isolates were found to be sensitive to meropenem and imipenem; however, the majority 
of strains were found to be resistant to ertapenem and azithromycin and moxifloxacin, indicating that these drugs should not be used for treatment of melioidosis (Karunakaran and Puthucheary, 2007).

A Taiwanese patient presenting with lifethreatening melioidosis, including acute respiratory distress, septic shock and organ dysfunction, was successfully treated with a combination of meropenem and recombinant-activated protein $\mathrm{C}$ (rhAPC). Although rhAPC has been reported to reduce septic shock caused by a number of pathogens, this is the first report of rhAPC being used to treat life-threatening melioidosis (Tan et al., 2007).

Novel therapeutics has involved the development of a phage-displayed non-immune human single-chain $\mathrm{Fv}$ (scFv) antibody library against whole-killed B. pseudomallei, and screening of this library has identified seven different phage scFv antibodies that interact with the organism (Zou et al., 2007). In addition, Defence Science and Technology Organisation (DSTO) has performed panning experiments using phage peptide libraries and shark antibody libraries for potential binders that recognize B. pseudomallei OmpA (J. McAllister, pers. comm.) and these are now able to be evaluated as potential therapeutic reagents.

\section{Plague}

For a brief summary of the type, mode/mechanism of action and signs and symptoms of plague, please refer to Table 1.

\section{Current prophylaxis for plague}

The recommended antibiotic for secondary postexposure prophylaxis is $100 \mathrm{mg}$ of doxycycline (child $>8$ years: $2.5 \mathrm{mg} \cdot \mathrm{kg}^{-1}$ up to $100 \mathrm{mg}$ ) twice a day, or $300 \mathrm{mg}$ ciprofloxacin i.v. twice a day for 9 days, followed by $500 \mathrm{mg}$ (child: $15 \mathrm{mg} \cdot \mathrm{kg}^{-1}$ up to $500 \mathrm{mg}$; p.o.) for an additional 6 days, twice a day. The World Health Organisation (WHO) also recommends 1-2 g.day ${ }^{-1}$ tetracycline (p.o.) at 6 or 12 hourly intervals, or $1.6 \mathrm{~g} \cdot \mathrm{day}^{-1}$ sulphamethoxazole or trimethoprim (p.o.) at 12 hourly intervals (p.o.) (Poland, 2009).

To improve the efficacy of the current plague subunit vaccine, protective fraction 1 capsular antigen (F1) and the virulence multifunctional LcrV antigen $(\mathrm{V})$ that resides at the tips of type III needle complexes (Baker et al., 1952; Lawton et al., 1963) are currently being engineered as recombinant F1-V proteins (Andrews et al., 1996; Heath et al., 1998; Williamson, 2001; Powell et al., 2005; Goodin et al., 2007). The F1-V fusion proteins together with alum- based delivery have been demonstrated by Dstl and USAMRIID to protect mice against pulmonary Yersinia pestis challenge. Currently both vaccines have entered phase I clinical trials and have been reported to be safe, well-tolerated and immunogenic (Heath et al., 1998; Jones et al., 2000; Williamson et al., 2005; Morris, 2007).

Further studies show that formulation of F1-V proteins with adjuvant induces strong humoral and cellular immunity (Glynn et al., 2005; Jones et al., 2006). Four different adjuvants: heat-labile enterotoxin (LT) (R192G), CpG ODN, MPL ${ }^{\circledR} \mathrm{TDM}$ and alum, have been administered in combination with recombinant F1-V protein, and have all effectively induced type 1/type 2 antibody responses. The magnitude of antibody response was evaluated in mice immunized via i.n., transcutaneous (t.c.) and s.c. routes. High levels of anti-F1-V IgG $\operatorname{Ig}_{1-2 a}$ in both the serum and bronchioalveolar lavage (BAL) were observed with s.c. route producing the greater response (Uddowla et al., 2007). Similarly, a recombinant F1-V protein coupled to a synthetic lipid, a mimetic known as amino-alkyl glucosaminide 4-phosphate (AGP), augmented cell-mediated $\mathrm{T}_{\mathrm{H}} 1$ immune responses in rats challenged with lethal $Y$. pestis strain C092. The AGP-based vaccine was administered according to a primary/secondary i.n. prime/boost regime and demonstrated that an initial immunization on day 1 followed by another on day 3 , protected $63 \%$ of rats by day 7 , subsequently achieving $100 \%$ protection by 21 days (Airhart et al., 2008).

A bicistronic DNA vaccine (i.n.) co-expressing F1-V fusion protein and a molecular adjuvant, IL-12, protected mice against $Y$. pestis challenge, in contrast to mice immunized with $\mathrm{F} 1-\mathrm{V}$ protein alone. Prime vaccination consisted of a low concentration of the DNA vector coding for IL-12 in conjunction with F1-V. Animals were subsequently boosted with recombinant F1 protein that provided protection from pneumonic plague (Yamanaka et al., 2008). The protective efficacies of flagellin adjuvant fused with F1-V protein and a plant-based oral plague vaccine without adjuvant, against respiratory challenge with $Y$. pestis $\mathrm{CO} 92$ have been demonstrated in mice and non-human primates (Mett et al., 2007; Arlen et al., 2008; Mizel et al., 2009).

The enhanced effectiveness of adjuvants in the development of plague vaccines against bubonic and pneumonic plague is evident. However, the major limitation to subunit vaccines is the necessity to administer multiple high dosages to produce robust and prolonged immune protection. With the emergence of $Y$. pestis antibiotic-resistant strains, the development of improved prophylactic approaches are of utmost importance. The 
discovery of strains lacking the F1 antigen is an important factor that must be considered in the design of new vaccines.

Yersinia pestis and $Y$. pseudotuberculosis share a close evolutionary relationship. An attenuated $Y$. pseudotuberculosis strain (IP32680; p.o.) was used to immunize mice against bubonic plague and resulted in high antibody responses and protection of $75 \%$ (after first dose) and 88\% (after second dose) of mice with no obvious adverse effects compared with animals immunized with the live attenuated $Y$. pestis strain EV76 (Blisnick et al., 2008). A mutant live vaccine was constructed by a deletion-insertion in the $I p \times M$ gene of $Y$. pestis EV NIIEG strain, denoted as $Y$. pestis EV $\Delta l p x M$. High protective efficacy of single dosing of $Y$. pestis EV $\Delta l p \times M$ was demonstrated in mice and guinea pigs (Bubeck and Dube, 2007).

An attenuated Salmonella enterica strain is frequently employed as a live vaccine vector encoding recombinant $\mathrm{F} 1-\mathrm{V}$ proteins. Vaccination with recombinant $\mathrm{F} 1-\mathrm{V}$ proteins (p.o.) induced specific F1-V specific IgG and IgA antibody titres that protected mice against $Y$. pestis challenge. Oral immunizations provided $>80 \%$ protection from $1000 \times$ $\mathrm{LD}_{50}$ bubonic plague and $100 \times \mathrm{LD}_{50}$ of pneumonic plague in mice. Hence, this attenuated Salmonellabased vaccine has potential as a plague vaccine (Liu et al., 2007; Yang et al., 2007).

Operons yadB and yadC operons have also demonstrated novel potential in the plague F1-V vaccine. These virulence factors assist bacterium in the invasion of epithelioid cells. Mice immunized with yadC elicited specific $\operatorname{IgG}_{1}$ antibody responses, and the release of pro-inflammatory cytokine was also observed (Murphy et al., 2007; Forman et al., 2008). Similarly, anti-translocon antibodies YopB, YopD, or a complex of YopBDE, protected mice against lethal challenge with F1-Y. pestis indicating that $\mathrm{mABs}$ specific for $\mathrm{F} 1, \mathrm{~V}$ antigens and the Yop translocon may be useful prophylactic or therapeutic approaches (Eyles et al., 2007; Ivanov et al., 2008).

Vaccines from adenovirus vectors encoding the anti- $\mathrm{V}$ antigen produce strong immune responses resulting in $93.3 \%$ protection following i.n. Y. pestis challenge (Sofer-Podesta et al., 2009). Recombinant V10 protein showed immunogenicity and protected cynomolgus macaques upon challenge with aerosolized pneumonic plague (Cornelius et al., 2008). These studies confirmed that humoral immunity plays an important role in preventing the development of this disease, and recent research has illustrated that cellular immunity also contributes to protection against plague (Philipovskiy and Smiley, 2007; Kummer et al., 2008).

\section{Current treatment for plague}

The CDC recommends gentamicin to treat plague patients with 3 to $7.5 \mathrm{mg} \cdot \mathrm{kg}^{-1} \cdot \mathrm{day}^{-1}$ via i.m. or vascular administration at $8 \mathrm{~h}$ intervals. The most effective antibiotic for the treatment of plague, specifically the pneumonic form is streptomycin at $30 \mathrm{mg} \cdot \mathrm{kg}^{-1} \cdot \mathrm{day}^{-1}$ up to a total of $2 \mathrm{~g} \cdot \mathrm{day}^{-1}$ every $12 \mathrm{~h}$ (i.m.). Alternative antibiotics for specific therapy include: chloramphenicol at $50 \mathrm{mg} \cdot \mathrm{kg}^{-1} \cdot \mathrm{day}^{-1}$ p.o. or i.v. at $6 \mathrm{~h}$ intervals for 10 days (suitable for bubonic and pneumonic plague); tetracyclines $15 \mathrm{mg} \cdot \mathrm{kg}^{-1}$ p.o. followed by 25 to $50 \mathrm{mg} \cdot \mathrm{kg}^{-1} \cdot \mathrm{day}^{-1}$ for 10 days; or ciprofloxacin $400 \mathrm{mg}$ and doxycycline delivered $200 \mathrm{mg} \cdot \mathrm{day}^{-1}$ p.o. at 12 or $24 \mathrm{~h}$ intervals (Poland, 2009).

\section{Q fever}

For a brief summary of the type, mode/mechanism of action and signs and symptoms of $Q$ fever infection, please refer to Table 1 .

\section{Current prophylaxis for $Q$ fever}

Post-exposure prophylaxis for adults and pregnant or breastfeeding women is a week of either: doxycycline $100 \mathrm{mg}$ p.o. every $12 \mathrm{~h}$, erythromycin $500 \mathrm{mg}$ p.o. every $3 \mathrm{~h}$, clarithromycin $500 \mathrm{mg}$ p.o. every $12 \mathrm{~h}$ or roxithromycin $150 \mathrm{mg}$ p.o. every $12 \mathrm{~h}$ (Pettineo et al., 2009). Children should receive treatment with the same antibiotic for 1 week at the following doses: doxycycline $100 \mathrm{mg}$ p.o. every $12 \mathrm{~h}$ for children up to 8 years of age and weighing $>45 \mathrm{~kg}$ or $2.2 \mathrm{mg} \cdot \mathrm{kg}^{-1}$ p.o. every $12 \mathrm{~h}$ if $<45 \mathrm{~kg}$; erythromycin $500 \mathrm{mg}$ p.o. every $3 \mathrm{~h}$ for children $>35 \mathrm{~kg}$ or $50 \mathrm{mg} \cdot \mathrm{kg}^{-1}$ p.o. every $12 \mathrm{~h}$ if $<35 \mathrm{~kg}$; clarithromycin $500 \mathrm{mg}$ p.o. every $12 \mathrm{~h}$ if $>40 \mathrm{~kg}$ or $7.5 \mathrm{mg} \cdot \mathrm{kg}^{-1}$ p.o. every $12 \mathrm{~h}$ if $<40 \mathrm{~kg}$; or roxithromycin $8 \mathrm{mg} \cdot \mathrm{kg}^{-1}$ p.o. every $12 \mathrm{~h}$ (Pettineo et al., 2009).

A whole-cell $\mathrm{Q}$ fever vaccine $(\mathrm{Q}-\mathrm{Vax})$, consisting of the formalin-inactivated Henzerling strain, is currently licensed for use in Australia, although prescreening for prior immunity is required to prevent adverse reactions due to egg hypersensitivity (Marmion, 2007). An unlicensed, purified Henzerling strain whole-killed vaccine administered via an i.n. device is also available through USAMRIID to immunize occupationally at-risk individuals (Waag, 2007). A chemo-vaccine comprising extracts of Coxiella burnetii lipopolysaccharide and protein has also been used to vaccinate laboratory workers and some industrial groups in Eastern Europe (Marmion, 2007).

A phase I chloroform-methanol residue (CMRI) vaccine has been developed as a safer alternative to 
the current whole-cell vaccines and is being assessed for safety and immunogenicity in phase I clinical trials (Waag et al., 2008). No antigen-specific antibody could be detected following a single subcutaneous prime; however, after a second booster, significant levels of specific antibody were produced. Peripheral blood cells collected from individuals following the booster also responded to recall antigen in vitro in a dose-dependent manner, suggesting that the vaccine is able to prime the immune system to effectively respond to infection (Waag et al., 2008).

A major way of preventing $Q$ fever is through vaccination of animal hosts serving as reservoirs of infection. Immunization of cattle with a monovalent inactivated phase I vaccine has been demonstrated to significantly lessen the probability of susceptible non-pregnant cows becoming shedders of the organism. This highlights the potential of implementing vaccination among non-infected herds to prevent spread of $\mathrm{Q}$ fever to humans (Guatteo et al., 2008).

Prophylaxis for $\mathrm{Q}$ fever has also focused on better characterization of the mechanisms of vaccineinduced immunity. This includes comparison of formalin-inactivated phase I and phase II vaccines in Balb/c mice. Phase I vaccines conveyed significant protection as well as Th1 dominant immune responses. Although phase II vaccines also induce Th1 immunity, they did not confer measurable protective responses, indicating that phase I lipopolysaccharide is important for host defence against C. burnetii (Zhang et al., 2007). The effects of infecting IFN- $\gamma$ and Toll-like receptor 2 knockout mice with the normally non-pathogenic phase II nine mile strain $C$. burnetii have also been investigated. The febrile response in these immunocompromised animals indicated that both IFN- $\gamma$ and TLR2 are important in providing protective immunity to C. burnetii, and that NMII is capable of causing disease in immunodeficient animals. These results highlight the usefulness of using these animals as models for evaluating vaccine candidates and hostpathogen interactions (Ochoa-Reparaz et al., 2007).

\section{Current treatment for $Q$ fever}

Generally acute $Q$ fever is a self-limiting mild or asymptomatic infection that resolves within 2 weeks, therefore treatment is not usually required (Tsironi et al., 2005). However, antibiotic therapy may be warranted to prevent progression to chronic disease. In such cases, the recommended regime is doxycycline $100 \mathrm{mg}$ twice daily for 14 days (Parker et al., 2006).

For chronic Q fever endocarditis, patients should receive a combination of doxycycline (100 $\mathrm{mg}$ twice daily) and hydroxychloroquine (200 mg three times daily) for a period of 18 months (Maurin and Raoult, 1999). Quinolones can also be used for patients intolerant to chloroquine (Maurin and Raoult, 1999). Long-term co-trimoxazole therapy $(320 \mathrm{mg}$ trimethoprim and $1600 \mathrm{mg}$ sulphamethoxazole for 35 days) is recommended for pregnant women to decrease the risk of placentitis, obstetric complications and maternal chronic Q fever infection (Carcopino et al., 2007).

Treatment of $\mathrm{Q}$ fever in pregnant women with doxycycline is contraindicated. Carcopino et al. (2007) investigated long-term co-trimoxazole therapy as treatment for pregnant women with $\mathrm{Q}$ fever and found that women were protected against chronic Q fever, placental infection and obstetric complications, particularly i.u. fetal death (found to be related to placental infection), when compared with women that had not received the therapy. This finding has led to the recommendation that longterm co-trimoxazole should be used to treat pregnant women with Q fever (Carcopino et al., 2007).

Interestingly, the CDC has assessed the risks and benefits of post-exposure antibiotic treatment following an intentional release of $C$. burnetii. Based on administration of doxycycline to the general population and co-trimoxazole to pregnant women, upper bound probability estimates of adverse effects to prophylaxis indicated that the risk of acquiring $\mathrm{Q}$ fever illness outweighed the risk of antimicrobial drug-related adverse effects (Moodie et al., 2008).

\section{Ricin}

For a brief summary of the type, mode/mechanism of action and signs and symptoms of ricin intoxication, please refer to Table 1 .

\section{Current prophylaxis for ricin}

There is currently no licensed ricin vaccine available. Ricin vaccine developments have previously focused on either deglycosylated ricin toxin A-chain (RTA) or formalin-inactivated toxoid (Doan, 2004). Both types of vaccine candidates have been shown to protect against aerosolized ricin poisoning in animals. However, both candidates have shortfalls; for example, formalin inactivation may not completely inactivate the toxin while deglycosylated RTA may lead to local or systemic vascular leak syndrome.

Recently, ricin vaccine development has utilized a recombinant technology approach to produce a non-toxic mutated form of ricin A-chain as a vaccine candidate. The vaccine candidate, RiVax, is a recombinant RTA in which two point mutations, Y80A and V76M, have been incorporated to remove 
its toxicity and vascular leak-inducing capacity (Smallshaw et al., 2002; 2005). The vaccine alone has been shown to be non-toxic and immunogenic in mice and rabbits (Smallshaw et al., 2002; 2005) and the first human clinical trial examining three i.m. doses $(10,33$ and $100 \mu \mathrm{g})$ has been completed (Vitetta et al., 2006). RiVax (i.m.) has been shown to prevent ricin-induced death (up to $10 \times \mathrm{LD}_{50}$ ) and tissue damage in mice administered ricin by either gavage or via aerosolization (Smallshaw et al., 2007). These findings are relevant to our understanding of treating ricin poisoning, which is most likely to occur following either accidental or intentional contamination of food, water or air.

To improve vaccine efficacy, vaccine formulation, adjuvant use and testing of delivery methods of recombinant ricin vaccines, have been investigated. USAMRIID have developed an optimal formulation for potential vaccine candidate RTA 1-33/ 44-198, a stable, non-toxic and immunogenic recombinant RTA (Carra et al., 2007). RTA 1-33/44198 is a RTA derivative containing deletions of the C-terminal sub-domain and an exposed surface loop (McHugh et al., 2004; Olson et al., 2004). Under the new formulation, the vaccine has shown to be highly stable and potent in storage for up to 18 months and has an increased adherence to aluminium hydroxide adjuvant from $15 \%$ to $91 \%$. In vivo studies in mice also reveal improvement in the vaccine's effective antigenicity by almost threefold (Olson et al., 2004).

Another recombinant RTA vaccine (rRV) prepared by mutating the $E$. coli LT has been assessed in combination with a mucosal adjuvant (Kende et al., 2007). Vaccination of mice (i.n.) with rRV alone offered marginal protection against aerosoldelivered $5-10 \times \mathrm{LD}_{50}$ of ricin toxin (Kende et al., 2007). The vaccine alone was only able to stimulate low anti-ricin neutralizing antibody responses. The protection of rRV vaccination was enhanced by co-administration of the mucosal adjuvant LTK63 or LTR72, two mutants of E. coli LT. Enterotoxigenic E. coli-expressed LT has been shown to act as a potent mucosal adjuvant, thereby inducing a strong immune response against co-administered antigens (p.o., i.n. or i.p.) (Clements et al., 1980; Jackson et al., 1993). However, the toxicity of LT makes it unsuitable for use in human vaccines. However, sitedirected mutagenesis has replaced single amino acids within the toxic subunit of LT, thus producing mutants LTK63 and LTR72 with no toxic activity. The study demonstrated that both mutants were effective and safe mucosal adjuvants that can enhance the protection of rRV against aerosoldelivered ricin challenge. However, the study also concluded that rRV with either LTK63 or LTR72 did not protect mice against ricin-related lung injuries (Kende et al., 2007).

Passive prophylaxis, such as antibody therapy, has been shown to be effective in neutralizing ricin intoxication. However, it should be noted that antibody treatment is limited to a few hours following ricin poisoning (Doan, 2004). Although mAbs are effective inhibitors of ricin, with in vitro and in vivo studies demonstrating the ability of mAbs to neutralize the toxic effects of ricin (Lemley et al., 1994; Furukawa-Stoffer et al., 1999), murine antibodies cannot be used as therapeutics due to side effects (Miller et al., 1983). To address this problem, a chimeric antibody, c4C13, has been constructed by coupling its parent murine antigen-binding variable domains to human constant domains. C4C13 has been demonstrated to neutralize the toxicity of ricin in in vitro assays (Wang et al., 2007b), suggesting that this 'humanized' component is a more suitable therapeutic.

To reduce anaphylaxis associated with antibody therapy, despeciated $\mathrm{F}\left(\mathrm{ab}^{\prime}\right)_{2}$ and Fab' antibody fragments are being developed for therapeutic use. Despeciated antibody fragments are considered to be safe as human products compared with polycloncal antibody (immunoglobulin G, IgG) that contains the species-related constant region, $F_{\mathrm{c}}$, which is likely to induce the anaphylactic reactions or other side effects. The protective efficacy of anti-ricin sheep IgG and $F\left(a b^{\prime}\right)_{2}$ administered i.v. to mice $2 \mathrm{~h}$ following systemic or inhalational challenge with ricin has been demonstrated (Griffiths et al., 2007). The smaller Fab' fragment did not prevent death from ricin intoxication. This study demonstrates the feasibility of effective anti-ricin antibodies and the smaller, less reactogenic fragments $\mathrm{F}\left(\mathrm{ab}^{\prime}\right)_{2}$ for use following exposure to ricin.

\section{Current treatment for ricin poisoning}

Currently, there are no licensed therapeutic antitoxins or antidotes available for ricin intoxication (Challoner and McCarron, 1990). Patient treatment is typically supportive care of symptoms (see Table 1). For oral intoxication, supportive care includes replacement of fluids and electrolytes i.v. to maintain electrolyte balance and prevent dehydration from vomiting and diarrhoea, and monitoring of liver and renal functions. Oral activated charcoal can be considered to reduce gastrointestinal adsorption of the toxin, although adsorption of ricin by charcoal is unknown (Chyka and Seger, 1997). For inhalational exposure, supportive care may include oxygen, bronchodilators, endotracheal intubation and supplemental positive end-expiratory pressure, as required (Audi et al., 2005). 
RNA ligands (aptamers) specific to the catalytic RTA have been investigated in vitro (Hesselberth et al., 2000). A 31-nucleotide RNA aptamer (31RA) has been demonstrated to bind to RTA, thereby blocking enzymatic activity of RTA (Fan et al., 2008). 31RA also neutralized the effects of ricin on translation inhibition in cell-free and cell-based luciferase assays, and ricin-induced cytotoxicity in in vitro assays. Although therapeutic effects of aptamers in in vivo models of ricin intoxication are still to be determined, in vitro results support the potential use of anti-RTA apatamer as ricin inhibitors.

\section{Smallpox}

For a brief summary of the type, mode/mechanism of action and signs and symptoms of smallpox, please refer to Table 1.

\section{Current prophylaxis for smallpox}

The global eradication of smallpox as a natural disease poses a major limitation on the ability of scientists to analyse the efficacy and safety of new smallpox vaccines or potential therapeutic agents. Current prophylaxis for smallpox may be divided into four categories: (i) replication-competent; (ii) replication-deficient viruses; (iii) recombinant proteins; and (iv) gene-based vectors. Given that the variola virus is no longer endemic, studies on the humoral and cell-mediated immunity must be presumed from similar orthopoxvirus infections, such as vaccinia, ectromelia, cowpox and monkeypox.

In addition to Dryvax, the first approved vaccine for smallpox since 1931, a second generation live vaccinia cell culture-based vaccine (ACAM2000 ${ }^{\mathrm{TM}}$ ) has been developed, registered and licensed in August 2007 (Monath et al., 2004; Greenberg and Kennedy, 2008). ACAM $2000^{\mathrm{TM}}$ is only manufactured by the US Government to vaccinate US troops. Phase III clinical trials indicate that neutralizing antibody levels $\sim 1.5$-fold lower than for Dryvax were induced in $97 \%$ of healthy and vaccinia naïve individuals following vaccination with ACAM2000 ${ }^{\mathrm{TM}}$. Data also indicated that $1-5 \times$ $10^{8} \mathrm{CFU} \cdot \mathrm{mL}^{-1}$ of ACAM2000 ${ }^{\mathrm{TM}}$ was sufficient to elicit cutaneous reactogenicity, immunogenicity and protective activity comparable to Dryvax (Weltzin et al., 2003; Artenstein et al., 2005). Although the homogenicity of ACAM2000 ${ }^{\mathrm{TM}}$ induces less neurovirulence and cutaneous reaction in animal models, the alarming incidence of postvaccination myopericarditis is one in 175 for vaccinia-naïve recipients (Weltzin et al., 2003; Frey et al., 2008; Marriott et al., 2008). Further clinical trials are required to better understand the complicated adverse events, such as myopericarditis, in ACAM2000 ${ }^{\mathrm{TM}}$ recipients.

Modified vaccinia Ankara (MVA) is a replicationdeficient and highly attenuated candidate that can be administered as an alternative vaccine against smallpox (Drexler et al., 1998; Slifka, 2005). MVA was registered as a pre-immunization vaccine in combination with Lister vaccine in Germany 1976 and was evaluated in animals and humans during the WHO smallpox eradication campaign (Mayr et al., 1978). The two-step vaccination noticeably reduced the severity of adverse effects, particularly in individuals with immune deficiency and atopic dermatitis, commonly seen with the traditional smallpox vaccine. Importantly, numerous preclini$\mathrm{cal}$ and clinical studies have demonstrated the safety and high immunogenicity of MVA (Belyakov et al., 2003; Earl et al., 2004; 2008; Meseda et al., 2005; Parrino et al., 2007). However, the long-term protective efficacy of MVA requires further investigation (Ferrier-Rembert et al., 2008).

IMVAMUNE $^{\circledR}$ is an attenuated smallpox vaccine that is genetically stable and does not replicate in human cells. Phase I/II clinical trials in individuals at risk of complication from the first and second generation vaccinia-based vaccines have confirmed a diminishment of serious health risks (Cassimatis et al., 2004; Vollmar et al., 2006). Phase III clinical trials will commence shortly, although preliminary results indicate that IMVAMUNE $^{\circledR}$ is well-tolerated, safe and immunogenic with no myocardial events (Frey et al., 2007; Kennedy and Greenberg, 2009).

Immunogenicity and efficacy by subcutaneous immunization of mice with a combination of MVA and IL-15 (an immune enhancing cytokine) have been demonstrated. This vaccine and cytokine combination induced both humoral and cellular responses, and the antibody responses were fourfold higher than those produced in mice given MVA alone (Perera et al., 2007).

The development of a potential subunit smallpox vaccine consisting of alternative variola protein candidates $(\mathrm{H} 3 \mathrm{~L}, \mathrm{~L} 1 \mathrm{R}, \mathrm{A} 27 \mathrm{~L}, \mathrm{~A} 33 \mathrm{R}$ and B5R) has recently been investigated. Preliminary data confirms that A27L, B5R and D8L proteins produced in E. coli are highly immunogenic and elicit strong protective immunity against viral challenge (He et al., 2007; Berhanu et al., 2008; Golden et al., 2008). A new approach to produce vaccinia virus $\mathrm{B} 5$ antigenic domain (pB5) in planta afforded mice protection from lethal challenge (Golovkin et al., 2007). Therefore, subunit vaccines may be useful vaccine candidates for the prophylaxis of smallpox. 


\section{Current treatment for smallpox}

Cidofovir (CDV, VistideTM) is currently the only licensed anti-viral drug approved by the US FDA to treat infections caused by variola and other orthopoxviruses (Jahrling et al., 2005). CDV is regulated under a restricted IND protocol and is often used as the positive control in orthopoxvirus studies in mice (Lalezari et al., 1997). CDV may only be administered when vaccinia immune globulin is not efficacious, although it has been shown to cause nephrotoxicity and is not orally bioavailable. In an effort to address these obstacles, four orally active lipid esters of CDV, HDP-CDV, ODBG-CDV, ODECDV and OLE-CDV were synthesized. HDP-CDV (CMX001, Chimerix Inc.) elicited the least nephrotoxicity and is potentially the most effective antiviral candidate. Hence, it is in a phase I multi-dose clinical trial to evaluate its safety and efficacy (Buller et al., 2004; Parker et al., 2008).

ST-246 (SIGA, Inc.), an orally bioavailable antiviral agent for orthopoxviruses, targets the F13L gene product that is required for production of extracellular virus. ST-246 is a potent vaccinia virus egress inhibitor that is effective in halting infection by orthopoxviruses. Preclinical studies have revealed the effectiveness of ST-246 (p.o.) following i.n. challenge with orthopoxvirus. In rabbits and squirrels, ST-246 treatment regime was conducted for a period of 10 to 14 days and was found to be safe and efficacious (Sbrana et al., 2007; Jordan et al., 2008; Nalca et al., 2008). Recently, administration of ST-246(R) to non-human primates provided 100\% protection with reduced viral load at 3 days post infection following lethal challenge with monkeypox virus. Phase I/II clinical trials have indicated that ST-246 is readily absorbed, well-tolerated and produces no severe adverse effects following a single dose (p.o.) of $2 \mathrm{~g}$ in fasting volunteers and $1 \mathrm{~g}$ in non-fasting volunteers (Jordan et al., 2008). Hence, ST-246 is a promising candidate as an anti-viral therapeutic in the treatment of smallpox.

Moreover, combinatorial treatment of smallpox with the traditional Dryvax vaccine and ST-246 has demonstrated anti-viral synergy, eliciting protective immunity and diminishing severity of lesions both in vitro and in vivo (Grosenbach et al., 2008). The combined treatment of ST-246 and CMX001 at doses of 1 and $3 \mathrm{mg} \cdot \mathrm{kg}^{-1} \cdot \mathrm{day}^{-1}$ has been shown to be synergistically effective in reducing mortality in mice following lethal challenge with vaccinia virus and cowpox virus, when compared with survival rates of animals receiving each drug alone (Quenelle et al., 2007). Further evaluation of these drugs is ongoing in clinical trials, but they are available for emergency purposes (Gupta et al., 2007). A recent case study reports combinatorial treatment involving St-246, CMX001 and the vaccinia immune globulin for a 28-month-old child who developed severe eczema vaccinatum from his father who had been vaccinated with vaccinia virus vaccine (Vora et al., 2008).

\section{Conclusion}

Despite decades of research, biological agents continue to be a threat to civilians and military personnel given the lack of prophylaxis and medical countermeasures available for a number of these agents. While there are vaccines commercially available for the prevention of anthrax, cholera, plague, $\mathrm{Q}$ fever and smallpox, there are no licensed vaccines available for use in the case of botulinum toxins, viral encephalitis, melioidosis or ricin. Antibiotics are still recommended as the mainstay treatment following exposure (or suspected exposure) to anthrax, plague, Q fever and melioidosis. Anti-toxin therapy and anti-virals may be used in the case of botulinum toxins or smallpox respectively. However, supportive care is the only, or mainstay, post-exposure treatment for cholera, viral encephalitis and ricin - a recommendation that has not changed in decades.

While further development and improvement of current regimes is required, there should be strategic alignment of resources and effort with the risk that biological agents pose (whether that be accidental or deliberate). In addition, the opportunities for international and national government and non-government organizations to collaborate and leverage from each others' work programmes should not be underestimated.

\section{Acknowledgement}

We thank Professor Wayne Hodgson (A/Head, Department of Pharmacology, Monash University, Australia) for his helpful comments.

\section{Conflict of Interest}

None of the contributing authors to this review have any conflict of interest to declare.

\section{References}

Aguilar PV, Weaver SC, Basler CF (2007). Capsid protein of eastern equine encephalitis virus inhibits host cell gene expression. J Virol 81: 3866-3876. 
Aguilar PV, Adams AP, Wang E, Kang W, Carrara AS, Anishchenko M et al. (2008a). Structural and nonstructural protein genome regions of eastern equine encephalitis virus are determinants of interferon sensitivity and murine virulence. J Virol 82: 4920-4930.

Aguilar PV, Leung LW, Wang E, Weaver SC, Basler CF (2008b). A five-amino-acid deletion of the eastern equine encephalitis virus capsid protein attenuates replication in mammalian systems but not in mosquito cells. J Virol 82: 6972-6983.

Airhart CL, Rohde HN, Bohach GA, Hovde CJ, Deobald CF, Lee SS et al. (2008). Induction of innate immunity by lipid A mimetics increases survival from pneumonic plague. Microbiology 154 (Pt 7): 2131-2138.

Andrews GP, Heath DG, Anderson GW, Jr, Welkos SL, Friedlander AM (1996). Fraction 1 capsular antigen (F1) purification from Yersinia pestis CO92 and from an Escherichia coli recombinant strain and efficacy against lethal plague challenge. Infect Immun 64: 2180-2187.

Anh DD, Canh do G, Lopez AL, Thiem VD, Long PT, Son NH et al. (2007). Safety and immunogenicity of a reformulated Vietnamese bivalent killed, whole-cell, oral cholera vaccine in adults. Vaccine 25: 1149-1155.

Arlen PA, Singleton M, Adamovicz JJ, Ding Y, Davoodi-Semiromi A, Daniell H (2008). Effective plague vaccination via oral delivery of plant cells expressing F1-V antigens in chloroplasts. Infect Immun 76: 3640-3650.

Arrigo NC, Watts DM, Frolov I, Weaver SC (2008). Experimental infection of Aedes sollicitans and Aedes taeniorhynchus with two chimeric Sindbis/Eastern equine encephalitis virus vaccine candidates. Am J Trop Med Hyg 78: 93-97.

Artenstein AW, Johnson C, Marbury TC, Morrison D, Blum PS, Kemp T et al. (2005). A novel, cell culture-derived smallpox vaccine in vaccinia-naive adults. Vaccine 23: 3301-3309.

Audi J, Belson M, Patel M, Schier J, Osterloh J (2005). Ricin poisoning: a comprehensive review. JAMA 294: 2342-2351.

Aulinger BA, Roehrl MH, Mekalanos JJ, Collier RJ, Wang JY (2005). Combining anthrax vaccine and therapy: a dominant-negative inhibitor of anthrax toxin is also a potent and safe immunogen for vaccines. Infect Immun 73: 3408-3414.

Baillie LW, Rodriguez AL, Moore S, Atkins HS, Feng C, Nataro JP et al. (2008). Towards a human oral vaccine for anthrax: the utility of a Salmonella Typhi Ty21a-based prime-boost immunization strategy. Vaccine 26: 6083-6091.

Baker EE, Sommer H, Foster LE, Meyer E, Meyer KF (1952). Studies on immunization against plague. I. The isolation and characterization of the soluble antigen of Pasteurella pestis. J Immunol 68: 131-145.

Barabe ND, Rayner GA, Christopher ME, Nagata LP, Wu JQ (2007). Single-dose, fast-acting vaccine candidate against western equine encephalitis virus completely protects mice from intranasal challenge with different strains of the virus. Vaccine 25: 6271-6276.

Barnes JL, Ketheesan N (2007). Development of protective immunity in a murine model of melioidosis is influenced by the source of Burkholderia pseudomallei antigens. Immunol Cell Biol 85: 551-557.

Barnes JL, Williams NL, Ketheesan N (2008).

Susceptibility to Burkholderia pseudomallei is associated with host immune responses involving tumor necrosis factor receptor-1 (TNFR1) and TNF receptor-2 (TNFR2). FEMS Immunol Med Microbiol 52: 379-388.

Behbehani AM (1983). The smallpox story: life and death of an old disease. Microbiol Rev 47: 455-509.

Belyakov IM, Earl P, Dzutsev A, Kuznetsov VA, Lemon M, Wyatt LS et al. (2003). Shared modes of protection against poxvirus infection by attenuated and conventional smallpox vaccine viruses. Proc Natl Acad Sci USA 100: 9458-9463.

Berhanu A, Wilson RL, Kirkwood-Watts DL, King DS, Warren TK, Lund SA et al. (2008). Vaccination of BALB/c mice with Escherichia coli-expressed vaccinia virus proteins A27L, B5R, and D8L protects mice from lethal vaccinia virus challenge. J Virol 82: 3517-3529.

Bielinska AU, Janczak KW, Landers JJ, Makidon P, Sower LE, Peterson JW et al. (2007). Mucosal immunization with a novel nanoemulsion-based recombinant anthrax protective antigen vaccine protects against Bacillus anthracis spore challenge. Infect Immun 75: 4020-4029.

Bina XR, Philippart JA, Bina JE (2009). Effect of the efflux inhibitors 1-(1-naphthylmethyl)-piperazine and phenyl-arginine-beta-naphthylamide on antimicrobial susceptibility and virulence factor production in Vibrio cholerae. J Antimicrob Chemother 63: 103-108.

Blisnick T, Ave P, Huerre M, Carniel E, Demeure CE (2008). Oral vaccination against bubonic plague using a live avirulent Yersinia pseudotuberculosis strain. Infect Immun 76: 3808-3816.

Bossi P, Tegnell A, Baka A, Van Loock F, Hendriks J, Werner A et al. (2004a). Bichat guidelines for the clinical management of anthrax and bioterrorism-related anthrax. Euro Surveill 9: E3-E4.

Bossi P, Tegnell A, Baka A, van Loock F, Hendriks J, Werner A et al. (2004b). Bichat guidelines for the clinical management of botulism and bioterrorism-related botulism. Euro Surveill 9: E13-E14.

Bossi P, Tegnell A, Baka A, Van Loock F, Hendriks J, Werner A et al. (2004c). Bichat guidelines for the clinical management of glanders and melioidosis and bioterrorism-related glanders and melioidosis. Euro Surveill bulletin europ ̃̃@en sur les maladies transmissibles = European communicable disease bulletin. 9: E17-E18.

Bouzianas DG (2007). Potential biological targets of Bacillus anthracis in anti-infective approaches against the threat of bioterrorism. Expert Rev Anti Infect Ther 5: 665-684. 
Brahmbhatt TN, Darnell SC, Carvalho HM, Sanz P, Kang TJ, Bull RL et al. (2007). Recombinant exosporium protein BclA of Bacillus anthracis is effective as a booster for mice primed with suboptimal amounts of protective antigen. Infect Immun 75: 5240-5247.

Breitbach K, Kohler J, Steinmetz I (2008). Induction of protective immunity against Burkholderia pseudomallei using attenuated mutants with defects in the intracellular life cycle. Trans R Soc Trop Med Hyg 102 (Suppl. 1): 589-594.

Brey RN (2005). Molecular basis for improved anthrax vaccines. Adv Drug Deliv Rev 57: 1266-1292.

Brook I, Elliott TB, Pryor HI, 2nd, Sautter TE, Gnade BT, Thakar JH et al. (2001). In vitro resistance of Bacillus anthracis Sterne to doxycycline, macrolides and quinolones. Int J Antimicrob Agents 18: 559-562.

Brossier F, Levy M, Mock M (2002). Anthrax spores make an essential contribution to vaccine efficacy. Infect Immun 70: 661-664.

Bubeck SS, Dube PH (2007). Yersinia pestis CO92 delta yopH is a potent live, attenuated plague vaccine. Clin Vaccine Immunol 14: 1235-1238.

Buller RM, Owens G, Schriewer J, Melman L, Beadle JR, Hostetler KY (2004). Efficacy of oral active ether lipid analogs of cidofovir in a lethal mousepox model. Virology 318: 474-481.

Cai S, Sarkar HK, Singh BR (1999). Enhancement of the endopeptidase activity of botulinum neurotoxin by its associated proteins and dithiothreitol. Biochemistry 38: 6903-6910.

Carcopino X, Raoult D, Bretelle F, Boubli L, Stein A (2007). Managing Q fever during pregnancy: the benefits of long-term cotrimoxazole therapy. Clin Infect Dis 45: $548-555$.

Carra JH, Wannemacher RW, Tammariello RF, Lindsey CY, Dinterman RE, Schokman RD et al. (2007). Improved formulation of a recombinant ricin A-chain vaccine increases its stability and effective antigenicity. Vaccine 25: 4149-4158.

Cassimatis DC, Atwood JE, Engler RM, Linz PE, Grabenstein JD, Vernalis MN (2004). Smallpox vaccination and myopericarditis: a clinical review. J Am Coll Cardiol 43: 1503-1510.

Challoner KR, McCarron MM (1990). Castor bean intoxication. Ann Emerg Med 19: 1177-1183.

Charles PC, Brown KW, Davis NL, Hart MK, Johnston RE (1997). Mucosal immunity induced by parenteral immunization with a live attenuated Venezuelan equine encephalitis virus vaccine candidate. Virology 228: 153-160.

Cheng AC, Stephens DP, Currie BJ (2003). Granulocyte colony stimulating factor (G-CSF) as an adjunct to antibiotics in the treatment of pneumonia in adults. Cochrane Database Syst Rev: CD004400.

Cheng AC, Fisher DA, Anstey NM, Stephens DP, Jacups SP, Currie BJ (2004). Outcomes of patients with melioidosis treated with meropenem. Antimicrob Agents Chemother 48: 1763-1765.
Cheng AC, Currie BJ (2005). Melioidosis: epidemiology, pathophysiology and management. Clinical Microbiology Reviews 18: 383-416.

Chetchotisakd P, Porramatikul S, Mootsikapun P, Anunnatsiri S, Thinkhamrop B (2001). Randomized, double-blind, controlled study of cefoperazone-sulbactam plus cotrimoxazole versus ceftazidime plus cotrimoxazole for the treatment of severe melioidosis. Clin Infect Dis 33: 29-34.

Chichester JA, Musiychuk K, de la Rosa P, Horsey A, Stevenson N, Ugulava N et al. (2007). Immunogenicity of a subunit vaccine against Bacillus anthracis. Vaccine 25: 3111-3114.

Chyka PA, Seger D (1997). Position statement: single-dose activated charcoal. American Academy of Clinical Toxicology; European Association of Poisons Centres and Clinical Toxicologists. J Toxicol Clin Toxicol 35: 721-741.

Clements JD, Yancey RJ, Finkelstein RA (1980). Properties of homogeneous heat-labile enterotoxin from Escherichia coli. Infect Immun 29: 91-97.

Cornelius CA, Quenee LE, Overheim KA, Koster F, Brasel TL, Elli D et al. (2008). Immunization with recombinant V10 protects cynomolgus macaques from lethal pneumonic plague. Infect Immun 76: 5588-5597.

Cuccui J, Easton A, Chu KK, Bancroft GJ, Oyston PCF, Titball RW et al. (2007). Development of signature-tagged mutagenesis in Burkholderia pseudomallei to identify genes important in survival and pathogenesis. Infect Immun 75: 1186-1195.

Cybulski RJ, Jr, Sanz P, McDaniel D, Darnell S, Bull RL, O'Brien AD (2008). Recombinant Bacillus anthracis spore proteins enhance protection of mice primed with suboptimal amounts of protective antigen. Vaccine 26: 4927-4939.

Das D, Nagata LP, Suresh MR (2007). Immunological evaluation of Escherichia coli expressed E2 protein of Western equine encephalitis virus. Virus Res 128: 26-33.

Davis JS, Currie BJ, Fisher DA, Huffam SE, Anstey NM, Price RN et al. (2003). Prevention of opportunistic infections in immunosuppressed patients in the tropical top end of the Northern Territory. Commun Dis Intell 27: $526-532$.

Day PJ, Pinheiro TJ, Roberts LM, Lord JM (2002). Binding of ricin A-chain to negatively charged phospholipid vesicles leads to protein structural changes and destabilizes the lipid bilayer. Biochemistry 41: 2836-2843.

Dembek ZF, Smith LA, Rusnak JM (2007). Botulism: cause, effects, diagnosis, clinical and laboratory identification, and treatment modalities. Disaster Med Public Health Prep 1: 122-134.

Dixon TC, Meselson M, Guillemin J, Hanna PC (1999). Anthrax. N Engl J Med 341: 815-826.

Doan LG (2004). Ricin: mechanism of toxicity, clinical manifestations, and vaccine development. A review. J Toxicol Clin Toxicol 42: 201-208. 
Drexler I, Heller K, Wahren B, Erfle V, Sutter G (1998). Highly attenuated modified vaccinia virus Ankara replicates in baby hamster kidney cells, a potential host for virus propagation, but not in various human transformed and primary cells. J Gen Virol 79 (Pt 2): $347-352$.

Earl PL, Americo JL, Wyatt LS, Eller LA, Whitbeck JC, Cohen GH et al. (2004). Immunogenicity of a highly attenuated MVA smallpox vaccine and protection against monkeypox. Nature 428: 182-185.

Earl PL, Americo JL, Wyatt LS, Espenshade O, Bassler J, Gong K et al. (2008). Rapid protection in a monkeypox model by a single injection of a replication-deficient vaccinia virus. Proc Natl Acad Sci USA 105: 10889-10894.

Easton A, Haque A, Chu K, Lukaszewski R, Bancroft GJ (2007). A critical role for neutrophils in resistance to experimental infection with Burkholderia pseudomallei. J Infect Dis 195: 99-107.

Eyles JE, Butcher WA, Titball RW, Hill J (2007). Concomitant administration of Yersinia pestis specific monoclonal antibodies with plague vaccine has a detrimental effect on vaccine mediated immunity. Vaccine 25: 7301-7306.

Fan S, Wu F, Martiniuk F, Hale ML, Ellington AD, Tchou-Wong KM (2008). Protective effects of anti-ricin A-chain RNA aptamer against ricin toxicity. World J Gastroenterol 14: 6360-6365.

Fenollar F, Fournier PE, Carrieri MP, Habib G, Messana T, Raoult D (2001). Risks factors and prevention of Q fever endocarditis. Clin Infect Dis 33: 312-316.

Ferrier-Rembert A, Drillien R, Tournier JN, Garin D, Crance JM (2008). Short- and long-term immunogenicity and protection induced by non-replicating smallpox vaccine candidates in mice and comparison with the traditional 1st generation vaccine. Vaccine 26: 1794-1804.

Fine DL, Roberts BA, Teehee ML, Terpening SJ, Kelly CL, Raetz JL et al. (2007). Venezuelan equine encephalitis virus vaccine candidate (V3526) safety, immunogenicity and efficacy in horses. Vaccine 25: 1868-1876.

Fine DL, Roberts BA, Terpening SJ, Mott J, Vasconcelos D, House RV (2008). Neurovirulence evaluation of Venezuelan equine encephalitis (VEE) vaccine candidate V3526 in nonhuman primates. Vaccine 26: 3497-3506.

Flick-Smith HC, Walker NJ, Gibson P, Bullifent H, Hayward S, Miller J et al. (2002). A recombinant carboxy-terminal domain of the protective antigen of Bacillus anthracis protects mice against anthrax infection. Infect Immun 70: 1653-1656.

Forman S, Wulff CR, Myers-Morales T, Cowan C, Perry RD, Straley SC (2008). yadBC of Yersinia pestis, a new virulence determinant for bubonic plague. Infect Immun 76: 578-587.
Frey SE, Newman FK, Kennedy JS, Sobek V, Ennis FA, Hill H et al. (2007). Clinical and immunologic responses to multiple doses of IMVAMUNE (Modified Vaccinia Ankara) followed by Dryvax challenge. Vaccine 25: 8562-8573.

Frey SE, Newman FK, Kennedy JS, Ennis F, Abate G, Hoft DF et al. (2008). Comparison of the safety and immunogenicity of ACAM1000, ACAM2000 and $\operatorname{Dryvax}((\mathrm{R}))$ in healthy vaccinia-naive adults. Vaccine 27: 1637-1644.

Furbee B, Wermuth M (1997). Life-threatening plant poisoning. Crit Care Clin 13: 849-888.

Furukawa-Stoffer TL, Mah DC, Cherwonogrodzky JW, Weselake RJ (1999). A novel biological-based assay for the screening of neutralizing antibodies to ricin. Hybridoma 18: 505-511.

Garmashova N, Atasheva S, Kang W, Weaver SC, Frolova E, Frolov I (2007). Analysis of Venezuelan equine encephalitis virus capsid protein function in the inhibition of cellular transcription. J Virol 81: 13552-13565.

Glomski IJ, Corre JP, Mock M, Goossens PL (2007). Cutting Edge: IFN-gamma-producing CD4 T lymphocytes mediate spore-induced immunity to capsulated Bacillus anthracis. J Immunol 178: 2646-2650.

Glynn A, Freytag LC, Clements JD (2005). Effect of homologous and heterologous prime-boost on the immune response to recombinant plague antigens. Vaccine 23: 1957-1965.

Golden JW, Josleyn MD, Hooper JW (2008). Targeting the vaccinia virus $\mathrm{L} 1$ protein to the cell surface enhances production of neutralizing antibodies. Vaccine 26: 3507-3515.

Golovkin M, Spitsin S, Andrianov V, Smirnov Y, Xiao Y, Pogrebnyak N et al. (2007). Smallpox subunit vaccine produced in Planta confers protection in mice. Proc Natl Acad Sci USA 104: 6864-6869.

Goodin JL, Nellis DF, Powell BS, Vyas VV, Enama JT, Wang LC et al. (2007). Purification and protective efficacy of monomeric and modified Yersinia pestis capsular F1-V antigen fusion proteins for vaccination against plague. Protein Expr Purif 53: 63-79.

Greenberg RN, Kennedy JS (2008). ACAM2000: a newly licensed cell culture-based live vaccinia smallpox vaccine. Expert Opin Investig Drugs 17: 555-564.

Griffiths GD, Phillips GJ, Holley J (2007). Inhalation toxicology of ricin preparations: animal models, prophylactic and therapeutic approaches to protection. Inhal Toxicol 19: 873-887.

Grosenbach DW, Jordan R, King DS, Berhanu A, Warren TK, Kirkwood-Watts DL et al. (2008). Immune responses to the smallpox vaccine given in combination with ST-246, a small-molecule inhibitor of poxvirus dissemination. Vaccine 26: 933-946. 
Guatteo R, Seegers H, Joly A, Beaudeau F (2008). Prevention of Coxiella burnetii shedding in infected dairy herds using a phase I $C$. burnetii inactivated vaccine. Vaccine 26: 4320-4328.

Gupta M, Alam S, Bhatnagar R (2007). Catalytically inactive anthrax toxin(s) are potential prophylactic agents. Vaccine 25: 8410-8419.

Hackstadt T, Williams JC (1981). Biochemical stratagem for obligate parasitism of eukaryotic cells by Coxiella burnetii. Proc Natl Acad Sci USA 78: 3240-3244.

Haraga A, West TE, Brittnacher MJ, Skerrett SJ, Miller SI (2008). Burkholderia thailandensis as a model system for the study of the virulence-associated type III secretion system of burkholderia pseudomallei. Infect Immun 76: 5402-5411.

Harding SV, Sarkar-Tyson M, Smither SJ, Atkins TP, Oyston PCF, Brown KA et al. (2007). The identification of surface proteins of Burkholderia pseudomallei. Vaccine 25: 2664-2672.

Harland DN, Chu K, Haque A, Nelson M, Walker NJ, Sarkar-Tyson M et al. (2007). Identification of a LolC homologue in Burkholderia pseudomallei, a novel protective antigen for melioidosis. Infect Immun 75: 4173-4180.

Harris R, Paxman J (1982). A Higher Form of Killing: The Secret History of Chemical and Biological Warfare. Hill and Wang: New York.

Harrison LM, Rallabhandi P, Michalski J, Zhou X, Steyert SR, Vogel SN et al. (2008). Vibrio cholerae flagellins induce Toll-like receptor 5-mediated interleukin-8 production through mitogen-activated protein kinase and NF-kappaB activation. Infect Immun 76: 5524-5534.

He Y, Manischewitz J, Meseda CA, Merchlinsky M, Vassell RA, Sirota L et al. (2007). Antibodies to the A27 protein of vaccinia virus neutralize and protect against infection but represent a minor component of Dryvax vaccine-induced immunity. J Infect Dis 196: 1026-1032.

Heath DG, Anderson GW, Jr, Mauro JM, Welkos SL, Andrews GP, Adamovicz J et al. (1998). Protection against experimental bubonic and pneumonic plague by a recombinant capsular F1-V antigen fusion protein vaccine. Vaccine 16: 1131-1137.

Hesselberth JR, Miller D, Robertus J, Ellington AD (2000). In vitro selection of RNA molecules that inhibit the activity of ricin A-chain. J Biol Chem 275: 4937-4942.

Hu WG, Chau D, Wu J, Jager S, Nagata LP (2007). Humanization and mammalian expression of a murine monoclonal antibody against Venezuelan equine encephalitis virus. Vaccine 25: 3210-3214.

Inoue K, Fujinaga Y, Watanabe T, Ohyama T, Takeshi K, Moriishi K et al. (1996). Molecular composition of Clostridium botulinum type A progenitor toxins. Infect Immun 64: 1589-1594.
Ivanov MI, Noel BL, Rampersaud R, Mena P, Benach JL, Bliska JB (2008). Vaccination of mice with a Yop translocon complex elicits antibodies that are protective against infection with F1-Yersinia pestis. Infect Immun 76: 5181-5190.

Jackson RJ, Fujihashi K, Xu-Amano J, Kiyono H, Elson CO, McGhee JR (1993). Optimizing oral vaccines: induction of systemic and mucosal B-cell and antibody responses to tetanus toxoid by use of cholera toxin as an adjuvant. Infect Immun 61: 4272-4279.

Jahrling PB, Fritz EA, Hensley LE (2005).

Countermeasures to the bioterrorist threat of smallpox. Curr Mol Med 5: 817-826.

Jahrling PB, Huggins JW, Ibrahim MS, Lawler JV, Martin JW (2007). Smallpox and related orthopoxviruses. In: Dembek ZF (ed.). Medical Aspects of Biological Warfare. Office of the Surgeon General and the Borden Institute: Washington, DC, pp. 215-240.

Jernigan DB, Raghunathan PL, Bell BP, Brechner R, Bresnitz EA, Butler JC et al. (2002). Investigation of bioterrorism-related anthrax, United States, 2001: epidemiologic findings. Emerg Infect Dis 8: 1019-1028.

Jiang XL, He ZM, Peng ZQ, Qi Y, Chen Q, Yu SY (2007). Cholera toxin $\mathrm{B}$ protein in transgenic tomato fruit induces systemic immune response in mice. Transgenic Res 16: 169-175.

Jones RG, Liu Y, Rigsby P, Sesardic D (2008). An improved method for development of toxoid vaccines and antitoxins. J Immunol Methods 337: 42-48.

Jones SM, Day F, Stagg AJ, Williamson ED (2000). Protection conferred by a fully recombinant sub-unit vaccine against Yersinia pestis in male and female mice of four inbred strains. Vaccine 19: 358-366.

Jones T, Adamovicz JJ, Cyr SL, Bolt CR, Bellerose N, Pitt LM et al. (2006). Intranasal Protollin/F1-V vaccine elicits respiratory and serum antibody responses and protects mice against lethal aerosolized plague infection. Vaccine 24: 1625-1632.

Jordan R, Tien D, Bolken TC, Jones KF, Tyavanagimatt SR, Strasser J et al. (2008). Single-dose safety and pharmacokinetics of ST-246, a novel orthopoxvirus egress inhibitor. Antimicrob Agents Chemother 52: 1721-1727.

Julander JG, Bowen RA, Rao JR, Day C, Shafer K, Smee DF et al. (2008a). Treatment of Venezuelan equine encephalitis virus infection with (-)-carbodine. Antiviral Res 80: 309-315.

Julander JG, Skirpstunas R, Siddharthan V, Shafer K, Hoopes JD, Smee DF et al. (2008b). C3H/HeN mouse model for the evaluation of antiviral agents for the treatment of Venezuelan equine encephalitis virus infection. Antiviral Res 78: 230-241.

Kang J, Lee MS, Watowich SJ, Gorenstein DG (2007). Combinatorial selection of a RNA thioaptamer that binds to Venezuelan equine encephalitis virus capsid protein. FEBS Lett 581: 2497-2502. 
Karunakaran R, Puthucheary SD (2007). Burkholderia pseudomallei: in vitro susceptibility to some new and old antimicrobials. Scand J Infect Dis 39: 858-861.

Kende M, Tan X, Wlazlowski C, Williams R, Lindsey C, Del Giudice G (2007). Enhancement of intranasal vaccination with recombinant chain $A$ ricin vaccine (rRV) in mice by the mucosal adjuvants LTK63 and LTR72. Vaccine 25: 3219-3227.

Kennedy JS, Greenberg RN (2009). IMVAMUNE: modified vaccinia Ankara strain as an attenuated smallpox vaccine. Expert Rev Vaccines 8: 13-24.

Klas SD, Petrie CR, Warwood SJ, Williams MS, Olds CL, Stenz JP et al. (2008). A single immunization with a dry powder anthrax vaccine protects rabbits against lethal aerosol challenge. Vaccine 26: 5494-5502.

Klinman DM, Currie D, Lee G, Grippe V, Merkel T (2007). Systemic but not mucosal immunity induced by AVA prevents inhalational anthrax. Microbes Infect 9: 1478-1483.

Kozel TR, Thorkildson P, Brandt S, Welch WH, Lovchik JA, AuCoin DP et al. (2007). Protective and immunochemical activities of monoclonal antibodies reactive with the Bacillus anthracis polypeptide capsule. Infect Immun 75: 152-163.

Kummer LW, Szaba FM, Parent MA, Adamovicz JJ, Hill J, Johnson LL et al. (2008). Antibodies and cytokines independently protect against pneumonic plague. Vaccine 26: 6901-6907.

Lalezari JP, Stagg RJ, Kuppermann BD, Holland GN, Kramer F, Ives DV et al. (1997). Intravenous cidofovir for peripheral cytomegalovirus retinitis in patients with AIDS. A randomized, controlled trial. Ann Intern Med 126: 257-263.

Lawton WD, Erdman RL, Surgalla MJ (1963). Biosynthesis and purification of $\mathrm{V}$ and $\mathrm{W}$ antigens in Pasteurella pestis. Tech Manuscr US Army Biol Lab 21: $1-15$.

Legutki JB, Nelson M, Titball R, Galloway DR, Mateczun A, Baillie LW (2007). Analysis of peptide mimotopes of Burkholderia pseudomallei

exopolysaccharide. Vaccine 25: 7796-7805.

Lemley PV, Amanatides P, Wright DC (1994). Identification and characterization of a monoclonal antibody that neutralizes ricin toxicity in vitro and in vivo. Hybridoma 13: 417-421.

Little SF (2005). Anthrax vaccines: a development update. BioDrugs 19: 233-245.

Little SF, Knudson GB (1986). Comparative efficacy of Bacillus anthracis live spore vaccine and protective antigen vaccine against anthrax in the guinea pig. Infect Immun 52: 509-512.

Liu WT, Hsu HL, Liang CC, Chuang CC, Lin HC, Liu YT (2007). A comparison of immunogenicity and protective immunity against experimental plague by intranasal and/or combined with oral immunization of mice with attenuated Salmonella serovar Typhimurium expressing secreted Yersinia pestis F1 and V antigen. FEMS Immunol Med Microbiol 51: 58-69.

McConnell MJ, Hanna PC, Imperiale MJ (2007). Adenovirus-based prime-boost immunization for rapid vaccination against anthrax. Mol Ther 15: 203-210.

McHugh CA, Tammariello RF, Millard CB, Carra JH (2004). Improved stability of a protein vaccine through elimination of a partially unfolded state. Protein Sci 13: 2736-2743.

Manayani DJ, Thomas D, Dryden KA, Reddy V, Siladi ME, Marlett JM et al. (2007). A viral nanoparticle with dual function as an anthrax antitoxin and vaccine. Plos Pathog 3: 1422-1431.

Marmion B (2007). Q fever: the long journey to control by vaccination. Med J Aust 186: 164-166.

Marriott KA, Parkinson CV, Morefield SI, Davenport R, Nichols R, Monath TP (2008). Clonal vaccinia virus grown in cell culture fully protects monkeys from lethal monkeypox challenge. Vaccine 26: 581-588.

Maurin M, Raoult D (1999). Q fever. Clin Microbiol Rev 12: $518-553$.

Mayr A, Stickl H, Muller HK, Danner K, Singer H (1978). [The smallpox vaccination strain MVA: marker, genetic structure, experience gained with the parenteral vaccination and behavior in organisms with a debilitated defence mechanism (author's transl)]. Zentralbl Bakteriol [B] 167: 375-390.

Meseda CA, Garcia AD, Kumar A, Mayer AE, Manischewitz J, King LR et al. (2005). Enhanced immunogenicity and protective effect conferred by vaccination with combinations of modified vaccinia virus Ankara and licensed smallpox vaccine Dryvax in a mouse model. Virology 339: 164-175.

Mett V, Lyons J, Musiychuk K, Chichester JA, Brasil T, Couch $\mathrm{R}$ et al. (2007). A plant-produced plague vaccine candidate confers protection to monkeys. Vaccine 25: 3014-3017.

Michel G, Petrakova O, Atasheva S, Frolov I (2007). Adaptation of Venezuelan equine encephalitis virus lacking 51-nt conserved sequence element to replication in mammalian and mosquito cells. Virology 362: 475-487.

Miller RA, Oseroff AR, Stratte PT, Levy R (1983). Monoclonal antibody therapeutic trials in seven patients with T-cell lymphoma. Blood 62: 988-995.

Mizel SB, Graff AH, Sriranganathan N, Ervin S, Lees CJ, Lively MO et al. (2009). Flagellin-F1-V fusion protein is an effective plague vaccine in mice and two species of nonhuman primates. Clin Vaccine Immunol 16: 21-28.

Monath TP, Caldwell JR, Mundt W, Fusco J, Johnson CS, Buller M et al. (2004). ACAM2000 clonal Vero cell culture vaccinia virus (New York City Board of Health strain) - a second-generation smallpox vaccine for biological defense. Int J Infect Dis 8 (Suppl. 2): S31-S44. 
Montecucco C, Molgo J (2005). Botulinal neurotoxins: revival of an old killer. Curr Opin Pharmacol 5: 274-279.

Moodie CE, Thompson HA, Meltzer MI, Swerdlow DL (2008). Prophylaxis after exposure to Coxiella burnetii. Emerg Infect Dis 14: 1558-1566.

Morris SR (2007). Development of a recombinant vaccine against aerosolized plague. Vaccine 25: 3115-3117.

Murphy BS, Wulff CR, Garvy BA, Straley SC (2007). Yersinia pestis YadC: a novel vaccine candidate against plague. Adv Exp Med Biol 603: 400-414.

Nalca A, Hatkin JM, Garza NL, Nichols DK, Norris SW, Hruby DE et al. (2008). Evaluation of orally delivered ST-246 as postexposure prophylactic and antiviral therapeutic in an aerosolized rabbitpox rabbit model. Antiviral Res 79: 121-127.

Nygren E, Holmgren J, Attridge SR (2008). Murine antibody responses following systemic or mucosal immunization with viable or inactivated Vibrio cholerae. Vaccine 26: 6784-6790.

O'Brien L (2007). Inhibition of multiple strains of Venezuelan equine encephalitis virus by a pool of four short interfering RNAs. Antiviral Res 75: 20-29.

Ochoa-Reparaz J, Sentissi J, Trunkle T, Riccardi C, Pascual DW (2007). Attenuated Coxiella burnetii phase II causes a febrile response in gamma interferon knockout and toll-like receptor 2 knockout mice and protects against reinfection. Infect Immun 75: 5845-5858.

Olson KB (1999). Aum Shinrikyo: once and future threat? Emerg Infect Dis 5: 513-516.

Olson MA, Carra JH, Roxas-Duncan V, Wannemacher RW, Smith LA, Millard CB (2004). Finding a new vaccine in the ricin protein fold. Protein Eng Des Sel 17: 391-397.

Oszvald M, Kang TJ, Tomoskozi S, Jenes B, Kim TG, Cha YS et al. (2008). Expression of cholera toxin B subunit in transgenic rice endosperm. Mol Biotechnol 40: 261-268.

Paessler S, Yun NE, Judy BM, Dziuba N, Zacks MA, Grund AH et al. (2007). Alpha-beta T cells provide protection against lethal encephalitis in the murine model of VEEV infection. Virology 367: 307-323.

Paessler S, Rijnbrand R, Stein DA, Ni H, Yun NE, Dziuba $\mathrm{N}$ et al. (2008). Inhibition of alphavirus infection in cell culture and in mice with antisense morpholino oligomers. Virology 376: 357-370.

Parker NR, Barralet JH, Bell AM (2006). Q fever. Lancet 367: 679-688.

Parker S, Touchette E, Oberle C, Almond M, Robertson A, Trost LC et al. (2008). Efficacy of therapeutic intervention with an oral ether-lipid analogue of cidofovir (CMX001) in a lethal mousepox model. Antiviral Res 77: 39-49.
Parola P, Raoult D (2007). Rickettsial Diseases. CRC Press: Boca Raton, FL. 379 pp.

Parrino J, McCurdy LH, Larkin BD, Gordon IJ, Rucker SE, Enama ME et al. (2007). Safety, immunogenicity and efficacy of modified vaccinia Ankara (MVA) against Dryvax challenge in vaccinia-naive and vaccinia-immune individuals. Vaccine 25: 1513-1525.

Perera LP, Waldmann TA, Mosca JD, Baldwin N, Berzofsky JA, Oh SK (2007). Development of smallpox vaccine candidates with integrated interleukin-15 that demonstrate superior immunogenicity, efficacy, and safety in mice. J Virol 81: 8774-8783.

Perkins SD, Williams AJ, O'Brien LM, Laws TR, Phillpotts RJ (2008). CpG used as an adjuvant for an adenovirus-based Venezuelan equine encephalitis virus vaccine increases the immune response to the vector, but not to the transgene product. Viral Immunol 21: 451-457.

Pettineo C, Aitchison R, Leikin SM, Vogel SN, Leikin JB (2009). Biological and chemical weapons of mass destruction: updated clinical therapeutic countermeasures since 2003. Am J Ther 16: 35-43.

Philipovskiy AV, Smiley ST (2007). Vaccination with live Yersinia pestis primes CD4 and CD8 T cells that synergistically protect against lethal pulmonary $Y$. pestis infection. Infect Immun 75: 878-885.

Pier CL, Tepp WH, Bradshaw M, Johnson EA, Barbieri JT, Baldwin MR (2008). Recombinant holotoxoid vaccine against botulism. Infect Immun 76: 437-442.

Pittman PR, Gibbs PH, Cannon TL, Friedlander AM (2001). Anthrax vaccine: short-term safety experience in humans. Vaccine 20: 972-978.

Pittman PR, Coonan KM, Gibbs PH, Scott HM, Cannon TL, McKee KT, Jr (2004). Long-term health effects of repeated exposure to multiple vaccines. Vaccine 23: 525-536.

Poland JD (2009). Plague Manual: Epidemiology, Distribution, Surveillance and Control. World Health Organization: Geneva, Switzerland.

Powell BS, Andrews GP, Enama JT, Jendrek S, Bolt C, Worsham P et al. (2005). Design and testing for a nontagged $\mathrm{F} 1-\mathrm{V}$ fusion protein as vaccine antigen against bubonic and pneumonic plague. Biotechnol Prog 21: 1490-1510.

Qadri F, Chowdhury MI, Faruque SM, Salam MA, Ahmed T, Begum YA et al. (2007). Peru-15, a live attenuated oral cholera vaccine, is safe and immunogenic in Bangladeshi toddlers and infants. Vaccine 25: 231-238.

Quenelle DC, Prichard MN, Keith KA, Hruby DE, Jordan R, Painter GR et al. (2007). Synergistic efficacy of the combination of ST-246 with CMX001 against orthopoxviruses. Antimicrob Agents Chemother 51: 4118-4124. 
Rao V, Hinz ME, Roberts BA, Fine D (2006). Toxicity assessment of Venezuelan Equine Encephalitis virus vaccine candidate strain V3526. Vaccine 24: 1710-1715.

Reed RP (1998). Castor oil seed poisoning: a concern for children. Med J Aust 168: 423-424.

Rhie GE, Jung HM, Kim BS, Mekalanos JJ (2008a). Construction of a Vibrio cholerae prototype vaccine strain O395-N1-E1 which accumulates cell-associated cholera toxin B subunit. Vaccine 26: 5443-5448.

Rhie GE, Jung HM, Park J, Kim BS, Mekalanos JJ (2008b). Construction of cholera toxin B subunit-producing Vibrio cholerae strains using the Mariner-FRT transposon delivery system. FEMS Immunol Med Microbiol 52: 23-28.

Robinson JP, Leitenberg M (1971). The Rise in CB Weapons. The Problem of Chemical and Biological Warfare. Almquist \& Wiksells: Stolkholm.

Rosales-Mendoza S, Soria-Guerra RE, Lopez-Revilla R, Moreno-Fierros L, Alpuche-Solis AG (2008). Ingestion of transgenic carrots expressing the Escherichia coli heat-labile enterotoxin B subunit protects mice against cholera toxin challenge. Plant Cell Rep 27: 79-84.

Rosas CT, Paessler S, Ni H, Osterrieder N (2008). Protection of mice by equine herpesvirus type 1 based experimental vaccine against lethal Venezuelan equine encephalitis virus infection in the absence of neutralizing antibodies. Am J Trop Med Hyg 78: 83-92.

Roy SK, Hossain MJ, Khatun W, Chakraborty B, Chowdhury S, Begum A et al. (2008). Zinc supplementation in children with cholera in Bangladesh: randomised controlled trial. BMJ 336: 266-268.

Russell-Lodrigue KE, Zhang GQ, McMurray DN, Samuel JE (2006). Clinical and pathologic changes in a guinea pig aerosol challenge model of acute $\mathrm{Q}$ fever. Infect Immun 74: 6085-6091.

Sbrana E, Jordan R, Hruby DE, Mateo RI, Xiao SY, Siirin M et al. (2007). Efficacy of the antipoxvirus compound ST-246 for treatment of severe orthopoxvirus infection. Am J Trop Med Hyg 76: 768-773.

Schild S, Nelson EJ, Camilli A (2008). Immunization with Vibrio cholerae outer membrane vesicles induces protective immunity in mice. Infect Immun 76: 4554-4563.

Schneemann A, Manchester M (2009). Anti-toxin antibodies in prophylaxis and treatment of inhalation anthrax. Future Microbiol 4: 35-43.

Scorpio A, Blank TE, Day WA, Chabot DJ (2006). Anthrax vaccines: Pasteur to the present. Cell Mol Life Sci 63: 2237-2248.

Scorpio A, Chabot DJ, Day WA, O’Brien DK, Vietri NJ, Itoh Y et al. (2007). Poly-gamma-glutamate capsule-degrading enzyme treatment enhances phagocytosis and killing of encapsulated Bacillus anthracis. Antimicrob Agents Chemother 51: 215-222.
Scorpio A, Tobery SA, Ribot WJ, Friedlander AM (2008). Treatment of experimental anthrax with recombinant capsule depolymerase. Antimicrob Agents Chemother 52: 1014-1020.

Segal G, Feldman M, Zusman T (2005). The Icm/Dot type-IV secretion systems of Legionella pneumophila and Coxiella burnetii. FEMS Microbiol Rev 29: 65-81.

Selvam P, Vijayalakshimi P, Smee DF, Gowen BB, Julander JG, Day CW et al. (2007). Novel 3-sulphonamido-quinazolin-4(3H)-one derivatives: microwave-assisted synthesis and evaluation of antiviral activities against respiratory and biodefense viruses. Antivir Chem Chemother 18: 301-305.

Sharma A, Raviv Y, Puri A, Viard M, Blumenthal R, Maheshwari RK (2007). Complete inactivation of Venezuelan equine encephalitis virus by 1,5-iodonaphthylazide. Biochem Biophys Res Commun 358: 392-398.

Sharma MK, Jani D, Thungapathra M, Gautam JK, Meena LS, Singh Y et al. (2008a). Expression of accessory colonization factor subunit A (ACFA) of Vibrio cholerae and ACFA fused to cholera toxin B subunit in transgenic tomato (Solanum lycopersicum). J Biotechnol 135: 22-27.

Sharma MK, Singh NK, Jani D, Sisodia R, Thungapathra M, Gautam JK et al. (2008b). Expression of toxin co-regulated pilus subunit A (TCPA) of Vibrio cholerae and its immunogenic epitopes fused to cholera toxin B subunit in transgenic tomato (Solanum lycopersicum). Plant Cell Rep 27: 307-318.

da Silva AP, Unks D, Lyu SC, Ma J, Zbozien-Pacamaj R, Chen X et al. (2008). In vitro and in vivo antimicrobial activity of granulysin-derived peptides against Vibrio cholerae. J Antimicrob Chemother 61: 1103-1109.

Simpson AJH, Suputtamongkol Y, Smith MD, Angus BJ, Rajanuwong A, Wuthiekanun V et al. (1999).

Comparison of imipenem and ceftazidime as therapy for severe melioidosis. Clin Infect Dis 29: 381-387.

Simpson LL (2004). Identification of the major steps in botulinum toxin action. Annu Rev Pharmacol Toxicol 44: 167-193.

Sinclair HR, Smejkal CW, Glister C, Kemp F, van den Heuvel E, de Slegte J et al. (2008). Sialyloligosaccharides inhibit cholera toxin binding to the GM1 receptor. Carbohydr Res 343: 2589-2594.

Singh BR (2000). Intimate details of the most poisonous poison. Nat Struct Biol 7: 617-619.

Singh BR (2006). Botulinum neurotoxin structure, engineering, and novel cellular trafficking and targeting. Neurotox Res 9: 73-92.

Sivalingam SP, Sim SH, Jasper LCW, Wang D, Liu Y, Ooi EE (2008). Pre- and post-exposure prophylaxis of experimental Burkholderia pseudomallei infection with doxycycline, amoxicillin/clavulanic acid and co-trimoxazole. Journal of Antimicrobial. Chemotherapy 61: 674-678. 
Slifka MK (2005). The future of smallpox vaccination: is MVA the key? Med Immunol 4: 2.

Smallshaw JE, Firan A, Fulmer JR, Ruback SL, Ghetie V, Vitetta ES (2002). A novel recombinant vaccine which protects mice against ricin intoxication. Vaccine 20: 3422-3427.

Smallshaw JE, Richardson JA, Pincus S, Schindler J, Vitetta ES (2005). Preclinical toxicity and efficacy testing of RiVax, a recombinant protein vaccine against ricin. Vaccine 23: 4775-4784.

Smallshaw JE, Richardson JA, Vitetta ES (2007). RiVax, a recombinant ricin subunit vaccine, protects mice against ricin delivered by gavage or aerosol. Vaccine 25:

7459-7469.

Smart JK (1997). Histroy of chemical and biological warfare: an American perspective. In: Sidell FR, Takafuji ET, Franz DR (eds). Medical Aspects of Chemical and Biological Warfare. Borden Institute, Walter Reed Army Medical Center: Washington, DC, pp. 9-86.

Smith LA, Rusnak JM (2007). Botulinum neurotoxin vaccines: past, present, and future. Crit Rev Immunol 27: 303-318.

Sofer-Podesta C, Ang J, Hackett NR, Senina S, Perlin D, Crystal RG et al. (2009). Adenovirus-mediated delivery of an anti- $\mathrm{V}$ antigen monoclonal antibody protects mice against a lethal Yersinia pestis challenge. Infect Immun 77: 1561-1568.

Stepanov AV, Marinin LI, Pomerantsev AP, Staritsin NA (1996). Development of novel vaccines against anthrax in man. J Biotechnol 44: 155-160.

Stokes MG, Titball RW, Neeson BN, Galen JE, Walker NJ, Stagg AJ et al. (2007). Oral administration of a Salmonella enterica-based vaccine expressing Bacillus anthracis protective antigen confers protection against aerosolized B. anthracis. Infect Immun 75: 1827-1834.

Suputtamongkol Y, Rajchanuwong A, Chaowagul W, Dance DAB, Smith MD, Wuthiekanun V et al. (1994). Ceftazidime vs. amoxicillin/clavulanate in the treatment of severe melioidosis. Clin Infect Dis 19: 846-853.

Tan CK, Chan KS, Yu WL, Chen CM, Cheng KC (2007). Successful treatment of life-threatening melioidosis with activated protein $\mathrm{C}$ and meropenem. J Microbiol Immunol Infect 40: 83-87.

Tan GYG, Liu Y, Sivalingam SP, Sim SH, Wang D, Paucod JC et al. (2008). Burkholderia pseudomallei aerosol infection results in differential inflammatory responses in BALB/C and C57Bl/6 mice. J Med Microbiol 57: 508-515.

Thakurta P, Bhowmik P, Mukherjee S, Hajra TK, Patra A, Bag PK (2007). Antibacterial, antisecretory and antihemorrhagic activity of Azadirachta indica used to treat cholera and diarrhea in India. J Ethnopharmacol 111: 607-612.

Torok TJ, Tauxe RV, Wise RP, Livengood JR, Sokolow R, Mauvais S et al. (1997). A large community outbreak of salmonellosis caused by intentional contamination of restaurant salad bars. JAMA 278: 389-395.
Tsironi M, Andriopoulos P, Fokas S, Nikokiris G, Mantzourani M, Assimakopoulos G et al. (2005). Acute Q fever lobar pneumonia: a case report. J Infect 51.

Turnbull PC (2002). Introduction: anthrax history, disease and ecology. Curr Top Microbiol Immunol 271: $1-19$.

Uddowla S, Freytag LC, Clements JD (2007). Effect of adjuvants and route of immunizations on the immune response to recombinant plague antigens. Vaccine 25 : 7984-7993.

Valero N, MarinaEspina L, Bonilla E, Mosquera J (2007). Melatonin decreases nitric oxide production and lipid peroxidation and increases interleukin-1 beta in the brain of mice infected by the Venezuelan equine encephalomyelitis virus. J Pineal Res 42: 107-112.

Vitetta ES, Smallshaw JE, Coleman E, Jafri H, Foster C, Munford R et al. (2006). A pilot clinical trial of a recombinant ricin vaccine in normal humans. Proc Natl Acad Sci USA 103: 2268-2273.

Vollmar J, Arndtz N, Eckl KM, Thomsen T, Petzold B, Mateo L et al. (2006). Safety and immunogenicity of IMVAMUNE, a promising candidate as a third generation smallpox vaccine. Vaccine 24: 2065-2070.

Vora S, Damon I, Fulginiti V, Weber SG, Kahana M, Stein SL et al. (2008). Severe eczema vaccinatum in a household contact of a smallpox vaccinee. Infect Clin Dis 46: 1555-1561.

Waag DM (2007). Coxiella burnetii: host and bacterial responses to infection. Vaccine 25: 7288-7295.

Waag DM, England MJ, Bolt CR, Williams JC (2008). Low-dose priming before vaccination with the phase I chloroform-methanol residue vaccine against $\mathrm{Q}$ fever enhances humoral and cellular immune responses to Coxiella burnetii. Clin Vaccine Immunol 15: 1505-1512.

Wang E, Petrakova O, Adams AP, Aguilar PV, Kang W, Paessler S et al. (2007a). Chimeric Sindbis/eastern equine encephalitis vaccine candidates are highly attenuated and immunogenic in mice. Vaccine 25: 7573-7581.

Wang Y, Guo L, Zhao K, Chen J, Feng J, Sun Y et al. (2007b). Novel chimeric anti-ricin antibody C4C13 with neutralizing activity against ricin toxicity. Biotechnol Lett 29: 1811-1816.

Wang JY, Roehrl MH (2005). Anthrax vaccine design: strategies to achieve comprehensive protection against spore, bacillus, and toxin. Med Immunol 4: 4 .

Webb RP, Smith TJ, Wright PM, Montgomery VA, Meagher MM, Smith LA (2007). Protection with recombinant Clostridium botulinum $\mathrm{C} 1$ and $\mathrm{D}$ binding domain subunit $(\mathrm{Hc})$ vaccines against $\mathrm{C}$ and $\mathrm{D}$ neurotoxins. Vaccine 25: 4273-4282.

Welkos SL, Friedlander AM (1988). Comparative safety and efficacy against Bacillus anthracis of protective antigen and live vaccines in mice. Microb Pathog 5: 127-139.

Weltzin R, Liu J, Pugachev KV, Myers GA, Coughlin B, Blum PS et al. (2003). Clonal vaccinia virus grown in cell culture as a new smallpox vaccine. Nat Med 9: 1125-1130. 
Williams TL, Jenkins AT (2008). Measurement of the binding of cholera toxin to GM1 gangliosides on solid supported lipid bilayer vesicles and inhibition by europium (III) chloride. J Am Chem Soc 130: 6438-6443.

Williamson ED (2001). Plague vaccine research and development. J Appl Microbiol 91: 606-608.

Williamson ED, Flick-Smith HC, Lebutt C, Rowland CA, Jones SM, Waters EL et al. (2005). Human immune response to a plague vaccine comprising recombinant F1 and $\mathrm{V}$ antigens. Infect Immun 73: 3598-3608.

Willis B, Eubanks LM, Dickerson TJ, Janda KD (2008). The strange case of the botulinum neurotoxin: using chemistry and biology to modulate the most deadly poison. Angew Chem Int Ed Engl 47: 8360-8379.

World Health Organization (2008). Cholera. Fact Sheet $\mathrm{N}^{\circ} 107$. [WWW document]. URL: http://www.who.int/en.

Worsham PL, McGovern TW, Vietri NJ, Friedlander AM (2007). Plague. In: Dembek ZF (ed.). Medical Aspects of Biological Warfare. Office of the Surgeon General and the Borden Institute: Washington, DC, pp. 91-119.

Wu JQ, Barabe ND, Chau D, Wong C, Rayner GR, $\mathrm{Hu}$ WG et al. (2007a). Complete protection of mice against a lethal dose challenge of western equine encephalitis virus after immunization with an adenovirus-vectored vaccine. Vaccine 25: 4368-4375.

Wu JQ, Barabe ND, Huang YM, Rayner GA, Christopher ME, Schmaltz FL (2007b). Pre- and post-exposure protection against Western equine encephalitis virus after single inoculation with adenovirus vector expressing interferon alpha. Virology 369: 206-213.

Yamanaka H, Hoyt T, Yang X, Golden S, Bosio CM, Crist K et al. (2008). A nasal interleukin-12 DNA vaccine coexpressing Yersinia pestis F1-V fusion protein confers protection against pneumonic plague. Infect Immun 76: 4564-4573.

Yan M, Liu G, Diao B, Qiu H, Zhang L, Liang W et al. (2007). A Vibrio cholerae serogroup O1 vaccine candidate against CTX ET Phi infection. Vaccine 25: 4046-4055.
Yang X, Hinnebusch BJ, Trunkle T, Bosio CM, Suo Z, Tighe $\mathrm{M}$ et al. (2007). Oral vaccination with salmonella simultaneously expressing Yersinia pestis F1 and V antigens protects against bubonic and pneumonic plague. J Immunol 178: 1059-1067.

Yu YZ, Sun ZW, Wang S, Yu WY (2007a). High-level expression of the Hcc domain of Clostridium botulinum neurotoxin serotype A in Escherichia coli and its immunogenicity as an antigen. Sheng Wu Gong Cheng Xue Bao 23: 812-817.

Yu YZ, Zhang SM, Sun ZW, Wang S, Yu WY (2007b). Enhanced immune responses using plasmid DNA replicon vaccine encoding the Hc domain of Clostridium botulinum neurotoxin serotype A. Vaccine 25: 8843-8850.

Yu YZ, Li N, Zhu HQ, Wang RL, Du Y, Wang S et al. (2009). The recombinant Hc subunit of Clostridium botulinum neurotoxin serotype A is an effective botulism vaccine candidate. Vaccine 27: 2816-2822.

Yuki Y, Kiyono H (2008). MucoRice: development of rice-based oral vaccine. Nihon Rinsho Meneki Gakkai Kaishi 31: 369-374.

Zeng M, Xu Q, Elias M, Pichichero ME, Simpson LL, Smith LA (2007). Protective immunity against botulism provided by a single dose vaccination with an adenovirus-vectored vaccine. Vaccine 25: 7540-7548.

Zhang G, Russell-Lodrigue KE, Andoh M, Zhang Y, Hendrix LR, Samuel JE (2007). Mechanisms of vaccine-induced protective immunity against Coxiella burnetii infection in BALB/c mice. J Immunol 179: 8372-8380.

Zhang RG, Scott DL, Westbrook ML, Nance S, Spangler BD, Shipley GG et al. (1995). The three-dimensional crystal structure of cholera toxin. J Mol Biol 251: 563-573.

Zhang Y, Qiu J, Zhou Y, Farhangfar F, Hester J, Lin AY et al. (2008). Plasmid-based vaccination with candidate anthrax vaccine antigens induces durable type 1 and type 2 T-helper immune responses. Vaccine 26: 614-622.

Zou N, Newsome T, Li B, Tsai S, Lo SC (2007). Human single-chain Fv antibodies against Burkholderia mallei and Burkholderia pseudomallei. Exp Biol Med 232: $550-556$. 